\title{
Acyloxylation of 1,4-Dioxanes and 1,4-Dithianes Catalyzed by a Copper-Iron Mixed Oxide
}

\author{
Ana Leticia García-Cabeza, ${ }^{\dagger}$ Rubén Marín-Barrios, ${ }^{\dagger}$ F. Javier Moreno-Dorado, ${ }^{\dagger}$ María J. Ortega, $^{\dagger}$ \\ Hilario Vidal, ${ }^{\ddagger}$ José M. Gatica, $^{\ddagger}$ Guillermo M. Massanet, ${ }^{\dagger}$ and Francisco M. Guerra* ${ }^{\dagger}$
}

${ }^{\dagger}$ Departamento de Química Orgánica and ${ }^{\ddagger}$ Departamento de Ciencia de los Materiales e Ingeniería Metalúrgica y Química Inorgánica, Facultad de Ciencias, Universidad de Cádiz, 11510 Puerto Real, Cádiz, Spain

Supporting Information

ABSTRACT: The use of a copper-iron mixed oxide as a heterogeneous catalyst for the efficient synthesis of $\alpha$-acyloxy-1,4-dioxanes and 1,4-dithianes employing $t$-butyl peroxyesters is reported. The preparation and characterization of the catalyst are described. The effect of the heteroatoms and a plausible mechanism are discussed. The method is operationally simple and involves low-cost starting materials affording products in good to excellent yields.

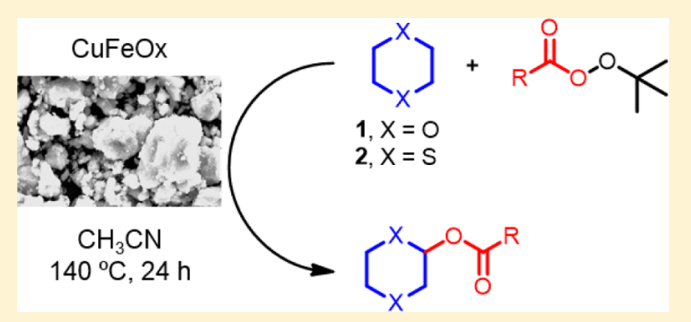

\section{INTRODUCTION}

The direct activation of $\mathrm{C}-\mathrm{H}$ bonds has experienced significant progress in the field of organic synthesis over the past decade. ${ }^{1}$ This kind of transformation poses important challenges, such as overcoming the inert nature of most $\mathrm{C}-\mathrm{H}$ bonds and the control of site selectivity. ${ }^{2}$ Some substrates, however, present the appropriate features for successful $\mathrm{C}-\mathrm{H}$ activation. The introduction of a new oxygenated functional group at $\mathrm{sp}^{3} \mathrm{C}-\mathrm{H}$ located $\alpha$ to an ethereal oxygen is feasible due to the relatively weak dissociation energy of this type of bond. ${ }^{3}$ Recently, the preparation of $\alpha$-acyloxy ethers has been studied by the Fu and Yuan group ${ }^{4}$ and the Patel group. ${ }^{5}$

In contrast, the preparation of their $\alpha$-acyloxy thioether siblings has received scarce attention. In 1982, Szarek and Hronowsky reported the preparation of 1,4-dithian-2-yl benzoate in $26 \%$ yield as an intermediate in the preparation of new pyrimidine nucleoside analogues with improved antitumor activity as surrogates of 5-fluorouracil (5-FUra). ${ }^{6}$ To the best of our knowledge, no other $\alpha$-acyloxy dithiane has been prepared.

Previous reports focused on the synthesis of $\alpha$-acyloxy ethers have based their success on the use of transition-metal catalysts, such as $\mathrm{Cu}^{7}$ and $\mathrm{Fe},{ }^{8}$ or by employing of tetrabutylammonium iodide $(\mathrm{TBAI})^{9}$ or $\mathrm{N}$-chlorosuccinimide $(\mathrm{NCS})^{10}$ (Scheme 2a).

Scheme 1. Preparation of Pyrimidine Nucleosides by Szarek and Hronowsky

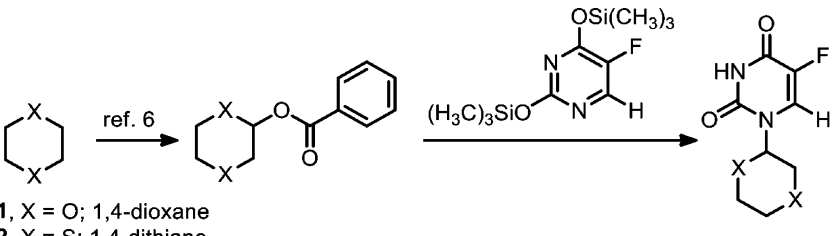

Scheme 2. Preparation of 1,4-Dioxane and 1,4-Dithiane Benzoates

a) Previous reports

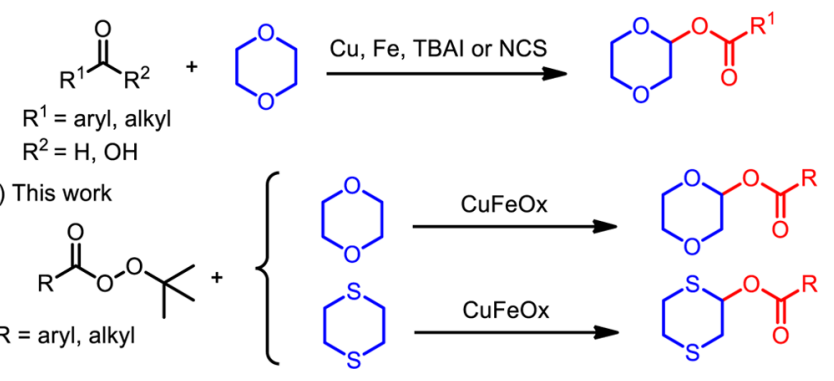

Copper and iron are considered low-risk metals in terms of supply and toxicity, ${ }^{11}$ which represents an advantage over other metals, such as those belonging to the platinum group. In this article, we present the use of a copper-iron mixed oxide ( $\mathrm{CuFeOx}$ henceforth), which effectively catalyzes the introduction of an $\alpha$ acyloxy group to the oxygen or sulfur atoms in 1,4-dioxanes and 1,4-dithianes (Scheme 2b).

Although mixed oxides have proven to be of help in the catalysis of oxidation reactions, ${ }^{12}$ their use in the field of organic synthesis has been rather limited. Recently, we have reported the allylic oxidation of alkenes and the $\gamma$-hydroxylation of enones by employing a copper-aluminum mixed oxide. ${ }^{13}$ This approach permits the synergistic action of two different metal centers over a substrate. Moreover, it allows the heterogenization of a process usually performed in a homogeneous way.

Received: May 11, 2015

Published: June 2, 2015 


\section{RESULTS AND DISCUSSION}

The preparation was carried out following our method for the synthesis of a copper-aluminum mixed oxide (for details on the preparation and characterization of the catalyst, see the Supporting Information). ${ }^{13 b, 14}$ The reproducibility of the $\mathrm{CuFeOx}$ preparation was ensured by submitting it to a characterization process. Observations by SEM revealed that the catalyst presented the form of a fine powder, with some irregularities in morphology and size, but in general consisting of micron-sized well-rounded grains. This study was complemented by granulometric measurements, which showed a distribution particle size in volume with relative maxima at approximately $0.8,9$, and $40 \mu \mathrm{m}$ that fit quite well with the size of the particles observed by SEM. In addition, a textural study was performed using $\mathrm{N}_{2}$ physisorption that indicated mesoporous character of the solid.

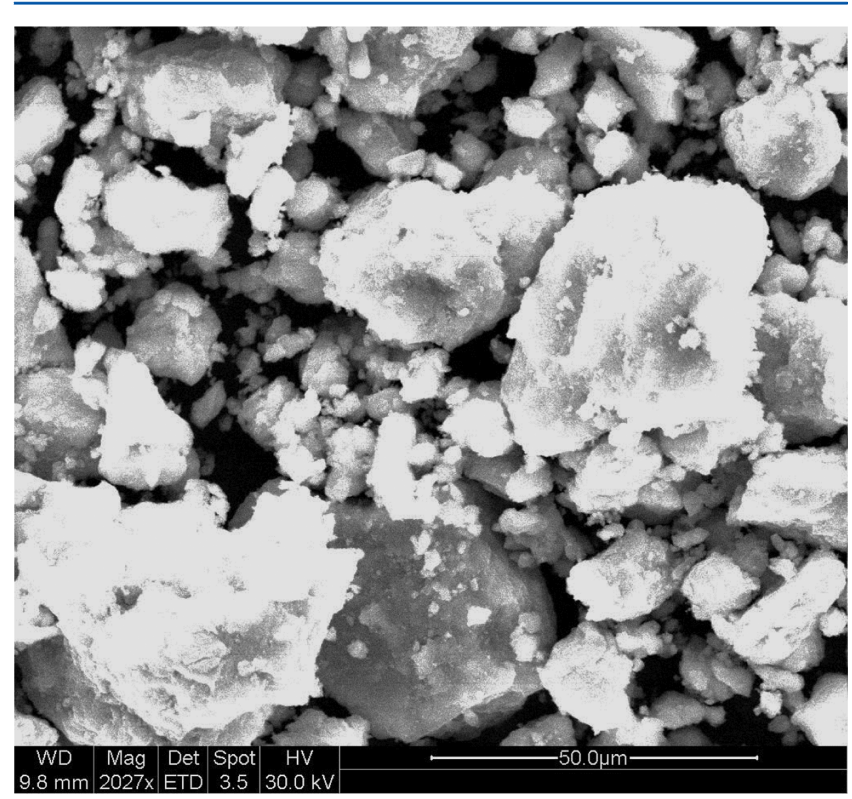

Figure 1. Typical scanning electron micrograph of the $\mathrm{CuFeOx}$ catalyst.

The raw X-ray diffraction diagram of the sample showed the presence of crystalline $\mathrm{CuO}$ in the tenorite phase. However, the use of Rietveld analysis allowed for detecting other phases, such as copper hydroxycarbonates (malachite and azurite) and spinel $\mathrm{CuFe}_{2} \mathrm{O}_{4}$ mixed oxides. The relatively lower intensity of ironcontaining phases can be reasonably related to the intrinsic limitations of the XRD technique, which prevents the detection of amorphous phases (the synthesis method followed does not favor obtaining crystalline materials) and underestimates ironrelated phases due to the well-known $\mathrm{Cu} \mathrm{K} \alpha$ absorption effect of this element. There was good agreement between compositional analysis data obtained by ICP, XRF, and EDS, thus indicating the homogeneity of the sample at both massive and micron-surface levels (Table 1). Moreover, they are relatively consistent with the $\mathrm{Cu} / \mathrm{Fe}$ atomic ratio selected for catalyst preparation and the formation of a copper-iron mixed oxide.

Once the catalyst was characterized, we focused on the reaction of 1,4-dioxane 1 with either benzaldehyde 3 or benzoic acid 5 using TBHP as the oxidant. The yields were moderate, affording the corresponding benzoyloxy 1,4-dioxane 4 in 35 and $31 \%$ yield, respectively (Table 2 , entries a and $b$ ).
Table 1. Compositional Analysis (wt \%) of the CuFeOx Sample by Means of Induced Coupled Plasma Spectroscopy, $\mathrm{X}$-ray Fluorescence, and Energy-Dispersive X-Ray Spectroscopy

\begin{tabular}{clll} 
technique & \multicolumn{1}{c}{$\mathrm{Cu}$} & \multicolumn{1}{c}{$\mathrm{Fe}$} & \multicolumn{1}{c}{$\mathrm{O}$} \\
$\mathrm{ICP}$ & $47.1 \pm 0.3$ & $17.2 \pm 0.1$ & not applicable \\
XRF & 51.5 & 22.4 & 24.0 \\
EDS $^{a}$ & $52.7 \pm 3.0$ & $18.1 \pm 1.5$ & 22.2
\end{tabular}

${ }^{a}$ Data correspond to the average of values obtained for four different areas analyzed in spot mode.

Table 2. Preliminary Assays ${ }^{a}$ (a)<smiles>C1COCCO1</smiles>

(b)<smiles>C1COCCO1</smiles>

(c)<smiles>C1COCCO1</smiles>

(d)<smiles>C1COCCO1</smiles>
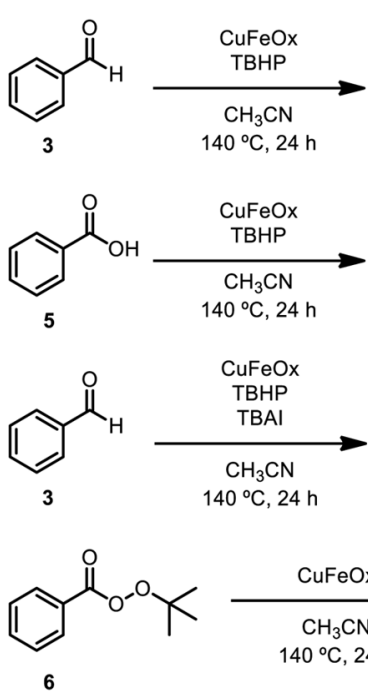<smiles>CC(C)(C)OOC(=O)c1ccccc1</smiles>

$0^{\circ} \mathrm{C}, 24 \mathrm{~h}$<smiles>CCCCCCCCCCCCCCCCCCCOC(=O)c1ccccc1</smiles><smiles>O=C(OC1COCCO1)c1ccccc1</smiles><smiles>O=C(OC1COCCO1)c1ccccc1</smiles><smiles>O=C(OC1COCCO1)c1ccccc1</smiles>

${ }^{a} \mathrm{GC}$ yield. Reaction conditions: 1,4-dioxane $1(5.0 \mathrm{mmol}), \mathrm{CuFeOx}$ (30 mg, $8.9 \mathrm{~mol} \% \mathrm{Cu}), \mathrm{CH}_{3} \mathrm{CN}(2 \mathrm{~mL}), 140{ }^{\circ} \mathrm{C}, 24 \mathrm{~h}$. (a) Benzaldehyde $3(2.5 \mathrm{mmol})$, TBHP ( $70 \%$ aqueous, $7.5 \mathrm{mmol})$. (b) Benzoic acid $5(2.5 \mathrm{mmol})$, TBHP (70\% aqueous, $7.5 \mathrm{mmol})$. (c) Benzaldehyde 3 ( $2.5 \mathrm{mmol}$ ), TBHP ( $70 \%$ aqueous, $7.5 \mathrm{mmol}$ ), TBAI (0.5 mmol). (d) TBPB 6 (2.5 mmol).

Recently, Wan et al. demonstrated that treatment of an aldehyde with TBAI and TBHP leads to the corresponding peroxyester that is in situ used as an oxidant in a KharaschSosnovsky oxidation of an olefin. ${ }^{15}$ In our case, the treatment of 1,4-dioxane 1 and benzaldehyde 3 with TBAI in the presence of $\mathrm{CuFeOx}$ was negative, leading to a mere $5 \%$ yield (Table 2, entry c). However, when we employed $t$-butyl peroxybenzoate (TBPB) as the oxidant, the reaction proceeded quantitatively (Table 2, entry d).

To assess the efficiency of $\mathrm{CuFeOx}$ as a catalyst, we subsequently tested various copper sources in our benchmark reaction, as shown in Table 3. It was observed that, in the absence of $\mathrm{CuFeOx}$ (entry 1), product 4 was formed in only $4 \%$ yield. The use of $\mathrm{Cu}(\mathrm{OAc})_{2} \cdot \mathrm{H}_{2} \mathrm{O}$ (entry 3 ) resulted in $44 \%$ yield, and the mixture of $\mathrm{CuFeOx}$ precursors, $\mathrm{CuCl}_{2}$, and $\mathrm{FeCl}_{3} \cdot 6 \mathrm{H}_{2} \mathrm{O}$ (entry 4 ) provided $65 \%$ yield. Other commercial oxides and chlorides, such as $\mathrm{Cu}_{2} \mathrm{O}, \mathrm{CuO}, \mathrm{CuCl}_{2}$, and $\mathrm{FeCl}_{3}$. $6 \mathrm{H}_{2} \mathrm{O}$ (entries 5-8) were also tested, producing the desired product in moderate yields. Entries 2 and 9-11 confirm the important role of temperature, displaying a dramatic drop in yield below $100{ }^{\circ} \mathrm{C}$.

Given that the use of TBPB 6 conducted to the desired $\alpha$ benzoyloxy 1,4-dioxane 4 in quantitative yield, we thought that 
Table 3. Search for the Optimal Catalyst ${ }^{a}$

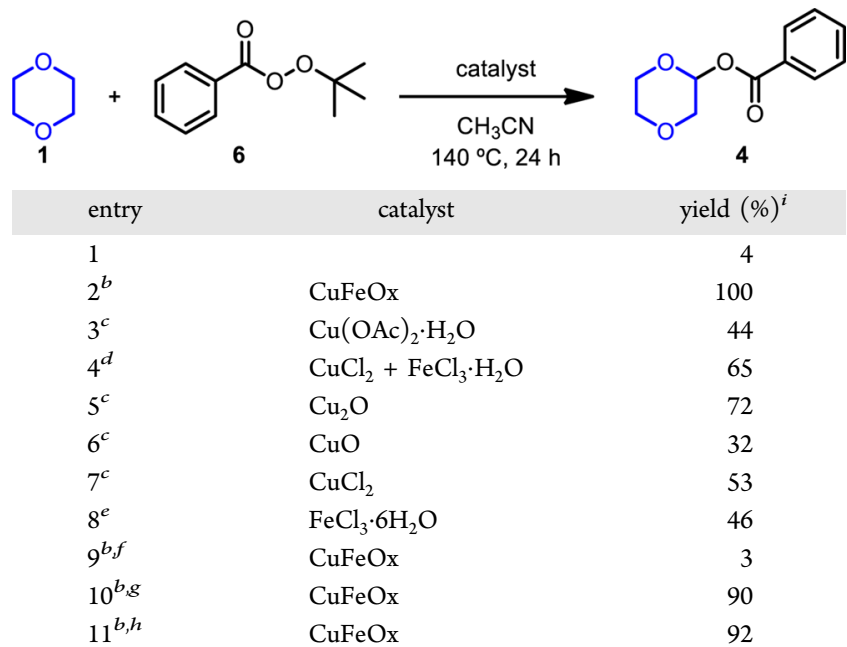

${ }^{a}$ Reaction conditions: 1,4-dioxane $1(5.0 \mathrm{mmol})$, TBPB $6(2.5 \mathrm{mmol})$, $\mathrm{CH}_{3} \mathrm{CN}(2 \mathrm{~mL}), 140{ }^{\circ} \mathrm{C}, 24 \mathrm{~h} .{ }^{b}$ Catalyst $(30 \mathrm{mg}, 8.9 \mathrm{~mol} \% \mathrm{Cu}, 3.7$ mol \% Fe). ${ }^{c}$ Catalyst $(8.9 \mathrm{~mol} \mathrm{\%} \mathrm{Cu}) .{ }^{d} \mathrm{CuCl}_{2}(17 \mathrm{mg})$ and $\mathrm{FeCl}_{3}$. $6 \mathrm{H}_{2} \mathrm{O}(13 \mathrm{mg}) .{ }^{e}$ Catalyst $(3.7 \mathrm{~mol} \% \mathrm{Fe}) .{ }^{f}$ At $80{ }^{\circ} \mathrm{C} .{ }^{g}$ At $100{ }^{\circ} \mathrm{C} .{ }^{h}$ At $120{ }^{\circ} \mathrm{C} .{ }^{i}$ Determined by GC.

the use of different peroxyesters would allow us to prepare different $\alpha$-acyloxy ethers.

The report by Wan et al. mentioned above describes a facile preparation of $t$-butyl peroxyesters from aldehydes catalyzed by TBAI. ${ }^{15}$ This methodology was found to be very reproducible, robust, and suitable for our purposes. Thus, we proceeded to the preparation of different peroxyesters that were reacted with 1,4-dioxane $\mathbf{1}$ in the presence of $\mathrm{CuFeOx}$ (Table 4). Gratifyingly, the reaction of aromatic peroxyesters furnished the corresponding $\alpha$-aryl esters $\mathbf{7 - 1 0}$ in good yields. The nature of the group attached to the aromatic ring of the peroxyester did not seem to affect the outcome, providing good yields in the presence of either donor or acceptor groups. The use of lineal $t$-butyl peroxyesters was also possible, as demonstrated by the formation of 1,4-dioxan-2-yl octanoate 11. The use of $t$-butyl 2-thienylperoxycarboxylate led to corresponding ester $\mathbf{1 2}$ in a good 73\% yield. A 1-naphthyl group could be introduced in the starting peroxyester, providing desired product 13 in $52 \%$ yield. An interesting case was that of the peroxyester prepared from cinnamaldehyde, which underwent a coupling reaction with a concomitant decarboxylative process, furnishing 1,4-dioxane derivative 14 . This kind of transformation has been previously reported by $\mathrm{Li}^{16}$ and $\mathrm{Han}^{17}$ groups in processes catalized by $\mathrm{CuO}$ and $\mathrm{Fe}(\mathrm{acac})_{3}$, respectively.

The exploration of the scope continued with 1,4-dithiane 2. Its behavior was parallel to that already described for 1,4dioxane 1. Thus, the respective aryl esters 15-19 were prepared with good to excellent yields. The yields of $\mathbf{2 0}$ and 21 were nevertheless significantly lower than those of $\mathbf{1 1}$ and 12. Naphthyl derivative 22 was obtained in $53 \%$ yield, a value similar to that obtained for 13. The main difference was observed in the treatment with the cinnamic acid peroxyester, where the decarboxylation was not observed, and the expected acyloxylated 1,4-dithiane 23 was produced in $26 \%$ yield.

General inspection of Table 4 indicates that the presence of two heteroatoms, either sulfur or oxygen, provides a suitable system for the acyloxylation reaction to take place. We found it convenient to evaluate the behavior of substrates bearing just
Table 4. Scope of 1,4-Dioxane and 1,4-Dithiane Derivatives ${ }^{a}$
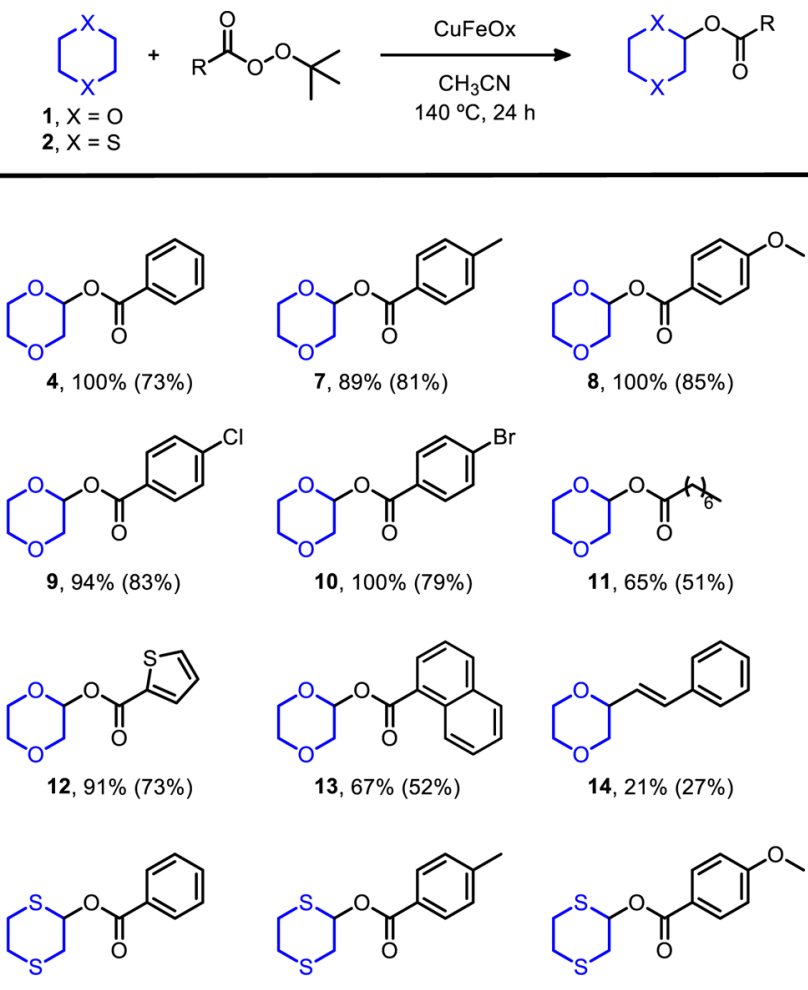<smiles>Cc1ccc(C(=O)OC2CSCCS2)cc1</smiles><smiles>COc1ccc(C(=O)OC2CSCCS2)cc1</smiles>

$15,87 \%(80 \%)$

$16,98 \%(89 \%)$

$17,93 \%(83 \%)$<smiles>O=C(OC1CSCCS1)c1ccc(Cl)cc1</smiles>

$18,76 \%(85 \%)$<smiles>O=C(OC1CSCCS1)c1cccs1</smiles>

$21,36 \%(41 \%)$<smiles>O=C(OC1CSCCS1)c1ccc(Br)cc1</smiles>

$19,97 \%(90 \%)$<smiles>O=C(OC1CSCCS1)c1cccc2ccccc12</smiles>

22, $55 \%(53 \%)$<smiles>CCCCCCCOC(=O)OC1CSCCS1</smiles>

$20,25 \%(23 \%)$<smiles>O=C(/C=C/c1ccccc1)OC1CSCCS1</smiles>

23, $42 \%(26 \%)$
${ }^{a} \mathrm{GC}$ yield is in parentheses. Reaction conditions: 1,4-dioxane 1 (5.0 $\mathrm{mmol})$ or 1,4-dithiane $2(2.0 \mathrm{mmol})$, peroxyester $(2.5 \mathrm{mmol}$ for 4 and 6-14 or $1.0 \mathrm{mmmol}$ for 15-23), $\mathrm{CuFeOx}$ (30 mg, $8.9 \mathrm{~mol} \% \mathrm{Cu}$ for 4 and 6-14 or $12 \mathrm{mg}, 8.9 \mathrm{~mol} \% \mathrm{Cu}$ for $15-23), \mathrm{CH}_{3} \mathrm{CN}(2 \mathrm{~mL})$ for 4 and 6-14, or $\mathrm{CH}_{3} \mathrm{CN}(1 \mathrm{~mL})$ and $\mathrm{CH}_{2} \mathrm{Cl}_{2}(1 \mathrm{~mL})$ for 15-23, 140 ${ }^{\circ} \mathrm{C}, 24 \mathrm{~h}$.

one heteroatom. The results are displayed in Table 5. Cyclic ethers, such as tetrahydropyran $\mathbf{2 4}$ and tetrahydrofuran $\mathbf{2 5}$, led to only traces of the corresponding benzoyloxy esters. Additionally, linear butyl methyl ether 26 provided the regioisomers $35 \mathbf{a}$ and $\mathbf{3 5} \mathbf{b}$ in a poor $23 \%$ overall yield (1:3.6 ratio). A slightly better yield (30\%) was obtained when a linear substrate bearing two oxygen atoms in 1,4-relative positions (27) was used. These results suggest that the presence of two oxygen atoms favors the reaction.

The importance of the relative location of the oxygen atoms was investigated further (Table 5). Although 1,3-dioxane 28 and 1,3-dioxolane 29 performed poorly, 2-methyl-1,3-dioxolane 30 furnished compounds $39 \mathrm{a}-\mathrm{c}$ in an overall yield of $66 \%$ (in a 13:2.5:1 ratio). This fact could be explained in terms of the relative stability of $\mathbf{2 9}$ and $\mathbf{3 0}$ (the acetals of formaldehyde and acetaldehyde, respectively) under the reaction conditions. Additionally, the tertiary nature of the resulting radical 
Table 5. Role of the Substitution Pattern in the Ether or Thioether ${ }^{a, b}$

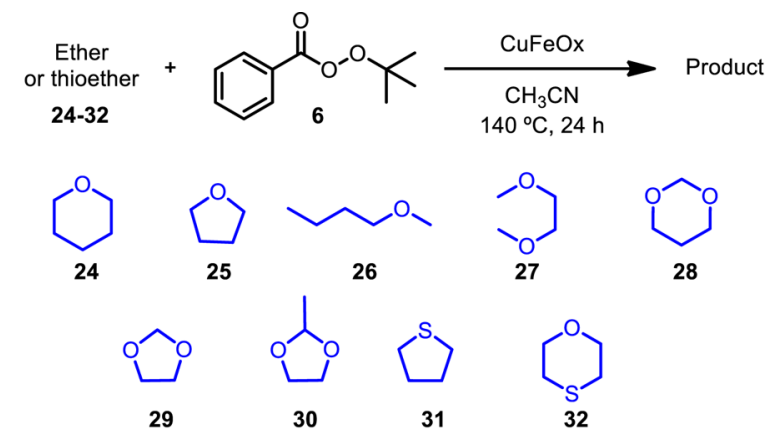

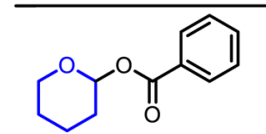

33, trace<smiles>CCCCOCOC(=O)c1ccccc1</smiles>

$35 \mathbf{b}, 15 \%(18 \%)^{c}$<smiles>O=C(OC1COCO1)c1ccccc1</smiles>

38, $16 \%(15 \%)$<smiles>CC1OC[C@@H](OC(=O)c2ccccc2)O1</smiles>

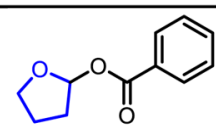

34, trace<smiles>COCC(OC)OC(=O)c1ccccc1</smiles><smiles>CC1(OC(=O)c2ccccc2)OCCO1</smiles>

$39 a, 54 \%(52 \%)^{d}$<smiles>O=C(OC1CCCS1)c1ccccc1</smiles><smiles>O=C(OC1CCCCO1)c1ccccc1</smiles>

41b, $18 \%(15 \%)^{e}$

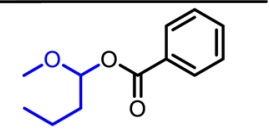

$35 a, 9 \%(5 \%)^{c}$
37 , trace

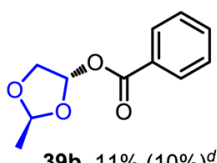<smiles>CCCCCCCCCCCCCCCCCCOC(=O)c1ccccc1</smiles>

${ }^{a}$ Reaction conditions: ethers 24-30 $(5.0 \mathrm{mmol})$, tetrahydrothiophene $31(2.0 \mathrm{mmol})$ or 1,4-oxathiane $32(5.0 \mathrm{mmol})$ and TBPB $(2.5 \mathrm{mmol}$ for 24-30 and 32 or $1.0 \mathrm{mmmol}$ for 31 ), $\mathrm{CuFeOx}(30 \mathrm{mg}, 8.9 \mathrm{~mol} \%$ $\mathrm{Cu}$ for 24-30 and 32 or $12 \mathrm{mg}, 8.9 \mathrm{~mol} \% \mathrm{Cu}$ for 31$), \mathrm{CH}_{3} \mathrm{CN}(2$ $\mathrm{mL})$ for 24-30 or $\mathrm{CH}_{3} \mathrm{CN}(1 \mathrm{~mL})$ and $\mathrm{CH}_{2} \mathrm{Cl}_{2}(1 \mathrm{~mL})$ for 31 and 32, $140{ }^{\circ} \mathrm{C}, 24 \mathrm{~h} .{ }^{b} \mathrm{GC}$ yield is in parentheses. ${ }^{c_{35}}$ a and $35 \mathrm{~b}$ formed in the same reaction $\left(23 \%\right.$ overall yield). ${ }^{d} 39 \mathrm{a}-\mathrm{c}$ formed in the same reaction ( $66 \%$ overall yield). ${ }^{e} 41 \mathrm{a}$ and $41 \mathrm{~b}$ formed in the same reaction ( $70 \%$ overall yield).

intermediate (vide infra) involved in the formation of 39a explains this result. Eventually, the presence of two oxygen atoms is required, preferably in a 1,4-relative position, for the reaction to proceed properly. It is noteworthy that, in contrast to tetrahydrofuran $\mathbf{2 5}$, tetrahydrothiophene $\mathbf{3 1}$ produced $\mathbf{4 0}$ in $46 \%$ yield. This seems to be in accordance with the higher activating ability of the sulfur atom. ${ }^{18}$ This idea was supported by the fact that 1,4-oxathiane 32 underwent acyloxylation primarily at the $\alpha$-position of the sulfur atom, leading to 41 a and $41 \mathrm{~b}$ in a $3.7: 1$ ratio ( $70 \%$ overall yield).

The radical nature of the mechanism was confirmed by a control reaction, employing 1,4-dioxane 1 as the substrate and TBPB as the oxidant in the presence of 2,6-di-t-butyl-4methylphenol (BHT), which led to the formation of $\mathbf{4}$ in just $2 \%$ yield.
Although $\mathrm{CuFeOx}$ presents a multicomponent nature, which makes it difficult to precisely define the origin of its activity, there are precedents of the use of copper-iron mixed oxides, such as $\mathrm{CuFe}_{2} \mathrm{O}_{4}$ in heterogeneous conditions in oxidative couplings. ${ }^{19}$ A proposed, plausible mechanism is depicted in Scheme 3. Decomposition of TBPB can be favored by the presence of the metallic centers (A). The solid provides a surface suitable for the formation of radicals and the encounter of the different species (B). The presence of the $t$-butoxyl radical would induce the formation of the radical at the $\alpha$ position of the ether or thiother (C). The higher yields obtained when two heteroatoms are present in the ether or the thioether suggest the coordination of one of these heteroatoms to a metallic center. The other oxygen or sulfur atom would activate its contiguous position by electron donation to the $\sigma^{*}$ orbital of the $\mathrm{C}-\mathrm{H}$ bond. ${ }^{20}$ The possibility of backbonding from the metal to the sulfur atom ${ }^{21}$ would explain that one sulfur atom is enough for the reaction to proceed in contrast to when only one oxygen atom is present. Once the radical is formed, coupling with the acyloxy moiety would take place, affording the corresponding product (D).

\section{CONCLUSION}

This work is an interesting example of the use of mixed oxides as catalysts for the activation of $\mathrm{C}-\mathrm{H}$ bonds. In particular, the acyloxylation at the $\alpha$-position of ethers and thioethers can be performed employing copper-iron mixed oxides in an efficient and clean way. In addition, there are limited precedents of the use of organic peroxides in heterogeneous catalysis. ${ }^{22}$ Conversely, although acyloxylation of 1,4-ethers has recently been studied, the use of the related 1,4-thioethers has not been reported with the exception of the Szarek and Hrownosky paper. $^{6}$ Last, but not least important, the presence of sulfur atoms in a substrate generally restricts the use of metallic catalysts due to catalyst poisoning. ${ }^{23}$ This fact limits the application of $\mathrm{C}-\mathrm{H}$ activation reactions in the search of sulfurbased heterocyclic drugs. In this sense, the use of copper-iron mixed oxides provides an efficient alternative to overcome this problem.

\section{EXPERIMENTAL SECTION}

General Information. NMR spectra were recorded on 400 or 500 $\mathrm{MHz}$ spectrometers using standard pulse sequences. Spectra were referenced to the internal chloroform $\left(\mathrm{CHCl}_{3}, \delta=7.25 \mathrm{ppm}\right.$ for ${ }^{1} \mathrm{H}$ NMR, $\delta=77.0 \mathrm{ppm}$ for ${ }^{13} \mathrm{C} \mathrm{NMR}$ ). GC analyses were performed using a DB-5 column. Octadecane was employed as an internal standard, and analyses were run in triplicate. Reactions were monitored through TLC on commercial silica gel plates precoated with silica gel. Visualization of the developed plate was performed by fluorescence quenching and aqueous ceric ammonium molybdate or anisaldehyde stains. HPLC purification was carried out using a $1 \times 25$ $\mathrm{cm}$ silica gel column $(10 \mu \mathrm{m}$ particle size). Fourier transform infrared spectroscopy (FTIR) spectra were recorded using $\mathrm{NaCl}$ plates, and data are reported in $\mathrm{cm}^{-1}$. Mass spectra were recorded on a UPLCQTOF mass spectrometer.

Compositional analysis of the copper-iron mixed oxide was studied by means of both inductively coupled plasma atomic emission spectroscopy (ICP-AES) and X-ray fluorescence (XRF). Textural characteristics were investigated by means of $\mathrm{N}_{2}$ physisorption at -196 ${ }^{\circ} \mathrm{C}$. The experiment was performed with a sample that was first subjected to a heat treatment under high vacuum at $150{ }^{\circ} \mathrm{C}$ for $2 \mathrm{~h}$. The recorded isotherms were used to obtain the specific surface area, $S_{\mathrm{BET}}$, and the porosity using the BET and $\mathrm{BJH}$ data treatment, respectively. Scanning electron microscopy (SEM) images and energy dispersive spectroscopy (EDS) compositional data were obtained with 
Scheme 3. Plausible Mechanism

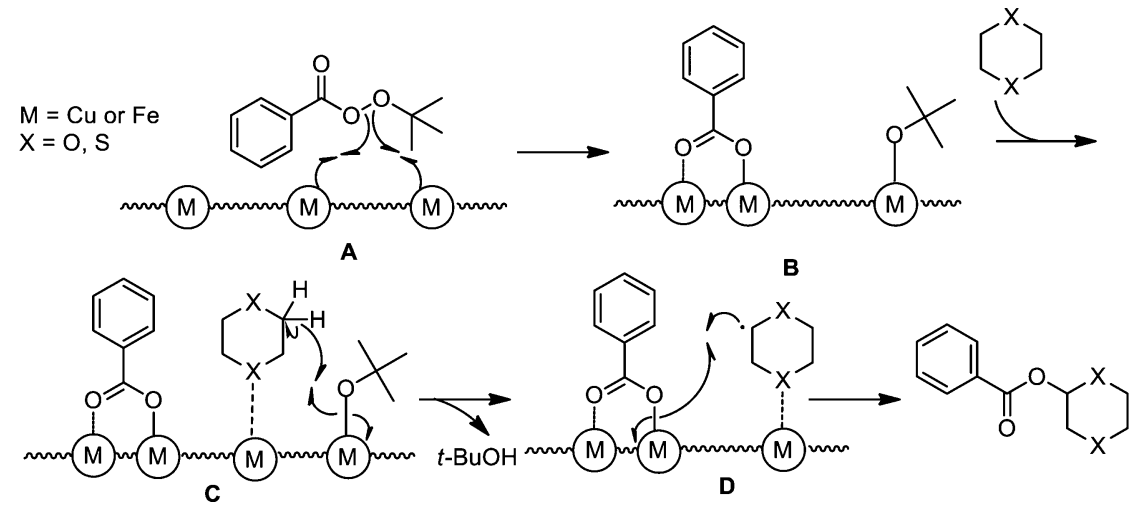

a scanning electron microscope using a nominal resolution of $3 \mathrm{~nm}$. Particle size distribution was obtained employing a granulometer operating with laser diffraction over a previously centrifuged dispersion of the sample ( 3 min sonicated) in water. Results were obtained from the average of the three tests performed to ensure reproducibility of the measurements. Structural studies were carried out with X-ray diffraction (XRD) at room temperature using a powder diffractometer operating with $\mathrm{Cu} \mathrm{K} \alpha$ radiation. The $2 \theta$ angle ranged from $3^{\circ}$ to $75^{\circ}$ with a step of $0.05^{\circ}$ and a counting time of $1 \mathrm{~s}$. The Rietveld method was applied to the XRD data using the FULLPROF program. ${ }^{24}$

Catalyst Preparation. ${ }^{13 \mathrm{~b}}$ The preparation of the copper-iron mixed oxide $(\mathrm{CuFeOx})$ was carried out following our method for the synthesis of copper-aluminum mixed oxide, which is based on that described by Guida et al. ${ }^{14}$ for the synthesis of hydrotalcites. To this end, a solution of $\mathrm{Na}_{2} \mathrm{CO}_{3}(1.27 \mathrm{~g})$ and $\mathrm{NaOH}(5.20 \mathrm{~g})$ in water $(100$ $\mathrm{mL}$ ) was added dropwise for $1.5 \mathrm{~h}$ over a solution containing $\mathrm{CuCl}_{2}$ $(5.00 \mathrm{~g})$ and $\mathrm{FeCl}_{3} \cdot 6 \mathrm{H}_{2} \mathrm{O}(4.00 \mathrm{~g})$ in water $(50 \mathrm{~mL})$. The suspension turned dark brown, and it was stirred at $70{ }^{\circ} \mathrm{C}$ for $22 \mathrm{~h}$. The mixture was then filtered, and the precipitate was washed with warm water (3 $\times 200 \mathrm{~mL}$ ). The solid was dried in an oven at $105^{\circ} \mathrm{C}$ for $24 \mathrm{~h}$, after which time it was ground until a fine powder was obtained. The solid was left exposed to air for $72 \mathrm{~h}$ prior to use.

General Procedure for the Synthesis of Peroxyesters. All peroxyesters have been prepared according to the literature procedure. ${ }^{15}$ The following two peroxyesters have been synthesized for the first time:

(E)-t-Butyl 3-Phenylprop-2-eneperoxoate. Colorless oil (894 mg, 20\%); ${ }^{1} \mathrm{H}$ NMR (400 MHz, $\left.\mathrm{CDCl}_{3}\right) \delta 7.60(\mathrm{~d}, J=16.0 \mathrm{~Hz}, 1 \mathrm{H}), 7.36$ $(\mathrm{dd}, J=6.7,2.9 \mathrm{~Hz}, 2 \mathrm{H}), 7.25-7.21(\mathrm{~m}, 3 \mathrm{H}), 6.27(\mathrm{~d}, J=16.0 \mathrm{~Hz}$, 1H), $1.24(\mathrm{~s}, 9 \mathrm{H}) ;{ }^{13} \mathrm{C}\left\{{ }^{1} \mathrm{H}\right\}$ NMR (100 MHz, $\left.\mathrm{CDCl}_{3}\right) \delta 164.7,145.5$, 133.5, 130.3, 128.5, 127.7, 112.7, 83.1, 25.7; IR (film) $\nu_{\max } 3063$, 2936, 2983,1755,1634, 1450,1367, 1190, 1108, 980, $763 \mathrm{~cm}^{-1}$; HRMS (ESI) calcd for $\mathrm{C}_{13} \mathrm{H}_{16} \mathrm{O}_{3} \mathrm{Na}[\mathrm{M}+\mathrm{Na}]^{+} 243.0997$, found 243.0997.

t-Butyl Octaneperoxoate. Colorless oil (804 mg, 18\%); ${ }^{1} \mathrm{H}$ NMR $\left(400 \mathrm{MHz}, \mathrm{CDCl}_{3}\right) \delta 2.28(\mathrm{t}, J=7.5 \mathrm{~Hz}, 2 \mathrm{H}), 1.64(\mathrm{tt}, J=7.5,7.5 \mathrm{~Hz}$, $2 \mathrm{H}), 1.30(\mathrm{~s}, 9 \mathrm{H}), 1.29-1.20(\mathrm{~m}, 8 \mathrm{H}), 0.85(\mathrm{t}, J=6.9 \mathrm{~Hz}, 3 \mathrm{H})$; ${ }^{13} \mathrm{C}\left\{{ }^{1} \mathrm{H}\right\} \mathrm{NMR}\left(100 \mathrm{MHz}, \mathrm{CDCl}_{3}\right) \delta 171.1,83.2,31.6,31.3,29.0,28.8$, 26.1, 25.0, 22.5, 14.0; IR (film) $\nu_{\max } 2957,2930,2859,1779,1467$, 1367, 1191, $854 \mathrm{~cm}^{-1}$; HRMS (ESI) calcd for $\mathrm{C}_{8} \mathrm{H}_{15} \mathrm{O}_{3}[\mathrm{M}-t \mathrm{Bu}]^{-}$ 159.1021, found 159.1015 .

General Procedure for the Acyloxylation of Ethers and 1,4Oxathiane. Thirty milligrams of $\mathrm{CuFeOx}$ was suspended in $2 \mathrm{~mL}$ of acetonitrile in a sealed tube, and the tube was stirred for $5 \mathrm{~min}$. Then, ether $(5.0 \mathrm{mmol})$ and $t$-butyl peroxyester $(2.5 \mathrm{mmol})$ were added, and the reaction mixture was stirred at $140{ }^{\circ} \mathrm{C}$. Caution! Considerable pressure can develop. After $24 \mathrm{~h}$, an aliquot was taken and analyzed by GC (using octadecane as an internal standard). The solvent was evaporated under reduced pressure, and the crude product was purified by SEPHADEX column chromatography with methanol as the eluent. For 1,4-oxathiane, $2 \mathrm{~mL}$ of acetonitrile/dichloromethane (1:1) was employed as the solvent.
General Procedure for the Acyloxylation of Thioethers. Twelve milligrams of $\mathrm{CuFeOx}$ was suspended in $1 \mathrm{~mL}$ of acetonitrile in a sealed tube, and the tube was stirred for $5 \mathrm{~min}$. Then, thioether $(2.0 \mathrm{mmol})$ and $t$-butyl peroxyester $(1.0 \mathrm{mmol}$, dissolved in $1 \mathrm{~mL}$ of dichloromethane) were added, and the reaction mixture was stirred at $140{ }^{\circ} \mathrm{C}$. Caution! Considerable pressure can develop. After $24 \mathrm{~h}$, an aliquot was taken and analyzed by GC (using octadecane as an internal standard). The solvent was evaporated under reduced pressure, and the crude product was purified by silica gel column chromatography with a mixture of EtOAc/hexanes as the eluent.

1,4-Dioxan-2-yl Benzoate (4). Colorless oil (380 mg, 73\%); ${ }^{1} \mathrm{H}$ $\operatorname{NMR}\left(500 \mathrm{MHz}, \mathrm{CDCl}_{3}\right) \delta 8.11(\mathrm{~d}, J=7.6 \mathrm{~Hz}, 2 \mathrm{H}), 7.58(\mathrm{tt}, J=7.5$, $1.8 \mathrm{~Hz}, 1 \mathrm{H}), 7.45(\mathrm{dd}, J=7.9,7.9 \mathrm{~Hz}, 2 \mathrm{H}), 6.09(\mathrm{br} \mathrm{s}, 1 \mathrm{H}), 4.21(\mathrm{ddd}$, $J=11.8,6.6,6.6 \mathrm{~Hz}, 1 \mathrm{H}), 3.89-3.87(\mathrm{~m}, 2 \mathrm{H}), 3.83-3.80(\mathrm{~m}, 2 \mathrm{H})$, 3.66 (ddd, $J=5.2,2.6,2.6 \mathrm{~Hz}, 1 \mathrm{H}) ;{ }^{13} \mathrm{C}\left\{{ }^{1} \mathrm{H}\right\}$ NMR $(126 \mathrm{MHz}$, $\left.\mathrm{CDCl}_{3}\right) \delta 165.2,133.3,129.9,129.7,128.4,89.8,67.8,66.1,61.7$; IR (film) $\nu_{\max } 2973,2858,1731,1601,1453,1259,1155,881,711 \mathrm{~cm}^{-1}$; HRMS (ESI) calcd for $\mathrm{C}_{11} \mathrm{H}_{12} \mathrm{O}_{4} \mathrm{Na}[\mathrm{M}+\mathrm{Na}]^{+} 231.0633$, found 231.0640

1,4-Dioxan-2-yl 4-Methylbenzoate (7). Yellowish oil (450 mg, $81 \%) ;{ }^{1} \mathrm{H}$ NMR $\left(400 \mathrm{MHz}, \mathrm{CDCl}_{3}\right) \delta 8.00(\mathrm{~d}, J=8.1 \mathrm{~Hz}, 2 \mathrm{H}), 7.25$ $(\mathrm{d}, J=8.0 \mathrm{~Hz}, 2 \mathrm{H}), 6.07(\mathrm{br} \mathrm{s}, 1 \mathrm{H}), 4.20$ (ddd, $J=12.0,6.5,6.5 \mathrm{~Hz}$, $1 \mathrm{H}), 3.89-3.86(\mathrm{~m}, 2 \mathrm{H}), 3.83-3.79(\mathrm{~m}, 2 \mathrm{H}), 3.66(\mathrm{ddd}, J=5.3,2.6$, $2.6 \mathrm{~Hz}, 1 \mathrm{H}), 2.41(\mathrm{~s}, 3 \mathrm{H}) ;{ }^{13} \mathrm{C}\left\{{ }^{1} \mathrm{H}\right\} \mathrm{NMR}\left(100 \mathrm{MHz}, \mathrm{CDCl}_{3}\right) \delta 165.3$, $144.2,129.9,129.1,126.9,89.6,67.9,66.1,61.8,21.7$; IR (film) $\nu_{\max }$ 2974, 2857, 1726, 1612, 1277, 1087, 883, $754 \mathrm{~cm}^{-1}$; HRMS (ESI) calcd for $\mathrm{C}_{12} \mathrm{H}_{13} \mathrm{O}_{4}[\mathrm{M}-\mathrm{H}]^{-}$221.0814, found 221.0818.

1,4-Dioxan-2-yl 4-Methoxybenzoate (8). White amorphous solid (506 mg, 85\%); ${ }^{1} \mathrm{H}$ NMR (400 MHz, $\left.\mathrm{CDCl}_{3}\right) \delta 8.05$ (d, $J=9.0$ $\mathrm{Hz}, 2 \mathrm{H}), 6.91$ (d, $J=9.0 \mathrm{~Hz}, 2 \mathrm{H}), 6.05$ (br s, $1 \mathrm{H}), 4.18$ (ddd, $J=11.8$, 5.5, $5.5 \mathrm{~Hz}, 1 \mathrm{H}), 3.86-3.85(\mathrm{~m}, 2 \mathrm{H}), 3.84(\mathrm{~s}, 3 \mathrm{H}), 3.81-3.78(\mathrm{~m}$, $2 \mathrm{H}), 3.65$ (ddd, $J=5.3,2.7,2.7 \mathrm{~Hz}, 1 \mathrm{H}) ;{ }^{13} \mathrm{C}\left\{{ }^{1} \mathrm{H}\right\}$ NMR $(100 \mathrm{MHz}$, $\left.\mathrm{CDCl}_{3}\right) \delta 164.9,163.7,132.0,122.0,113.7,89.5,67.9,66.1,61.8,55.4$; IR (film) $\nu_{\max } 2972,2856,1720,1607,1512,1257,1170,1088,1020$, 913, 883, $771 \mathrm{~cm}^{-1}$; HRMS (ESI) calcd for $\mathrm{C}_{12} \mathrm{H}_{14} \mathrm{O}_{5} \mathrm{Na}[\mathrm{M}+\mathrm{H}]^{+}$ 261.0739, found 261.0736.

1,4-Dioxan-2-yl 4-Chlorobenzoate (9). White amorphous solid (504 mg, 83\%); ${ }^{1} \mathrm{H}$ NMR (400 MHz, $\left.\mathrm{CDCl}_{3}\right) \delta 8.04(\mathrm{~d}, J=8.8 \mathrm{~Hz}$, $2 \mathrm{H}), 7.42(\mathrm{~d}, J=8.8 \mathrm{~Hz}, 2 \mathrm{H}), 6.07$ (br s, $1 \mathrm{H}), 4.19$ (ddd, $J=11.8,6.6$, $6.6 \mathrm{~Hz}, 1 \mathrm{H}), 3.88-3.87(\mathrm{~m}, 2 \mathrm{H}), 3.83-3.81(\mathrm{~m}, 2 \mathrm{H}), 3.67(\mathrm{ddd}, J=$ 5.1, 2.6, $2.6 \mathrm{~Hz}, 1 \mathrm{H}) ;{ }^{13} \mathrm{C}\left\{{ }^{1} \mathrm{H}\right\}$ NMR $\left(100 \mathrm{MHz}, \mathrm{CDCl}_{3}\right) \delta 164.4$, 139.9, 131.2, 128.8, 128.1, 90.0, 67.7, 66.1, 61.8; IR (film) $\nu_{\max } 2960$, $2856,1718,1594,1236,1152,1087,882,758 \mathrm{~cm}^{-1}$; HRMS (ESI) calcd for $\mathrm{C}_{11} \mathrm{H}_{10} \mathrm{O}_{4}{ }^{35} \mathrm{Cl}[\mathrm{M}-\mathrm{H}]^{-} 241.0268$, found 241.0258; calcd for $\mathrm{C}_{11} \mathrm{H}_{10} \mathrm{O}_{4}{ }^{37} \mathrm{Cl}[\mathrm{M}-\mathrm{H}]^{-} 243.0238$, found 243.0250 .

1,4-Dioxan-2-yl 4-Bromobenzoate (10). White amorphous solid (567 mg, 79\%); ${ }^{1} \mathrm{H}$ NMR (400 MHz, $\left.\mathrm{CDCl}_{3}\right) \delta 7.97$ (d, $J=$ $8.8 \mathrm{~Hz}, 2 \mathrm{H}), 7.59$ (d, $J=8.8 \mathrm{~Hz}, 2 \mathrm{H}), 6.07(\mathrm{br} \mathrm{s}, 1 \mathrm{H}), 4.19$ (ddd, $J=$ $13.3,6.6,6.6 \mathrm{~Hz}, 1 \mathrm{H}), 3.88-3.86(\mathrm{~m}, 2 \mathrm{H}), 3.83-3.81(\mathrm{~m}, 2 \mathrm{H}), 3.67$ (ddd, $J=5.2,2.6,2.6 \mathrm{~Hz}, 1 \mathrm{H}) ;{ }^{13} \mathrm{C}\left\{{ }^{1} \mathrm{H}\right\}$ NMR $\left(100 \mathrm{MHz}, \mathrm{CDCl}_{3}\right) \delta$ 164.5, 131.8, 131.4, 128.6, 90.0, 67.8, 66.1, 61.8; IR (film) $\nu_{\max } 2974$, $2863,1727,1589,1260,1068,880,746 \mathrm{~cm}^{-1}$; HRMS (ESI) calcd for 
$\mathrm{C}_{11} \mathrm{H}_{11} \mathrm{O}_{4}{ }^{79} \mathrm{BrNa}[\mathrm{M}+\mathrm{Na}]^{+}$308.9738, found 308.9749; calcd for $\mathrm{C}_{11} \mathrm{H}_{11} \mathrm{O}_{4}{ }^{81} \mathrm{BrNa}[\mathrm{M}+\mathrm{Na}]^{+}$310.9718, found 308.9756 .

1,4-Dioxan-2-yl Octanoate (11). Yellow oil (294 mg, 51\%); ${ }^{1} \mathrm{H}$ NMR (400 MHz, $\left.\mathrm{CDCl}_{3}\right) \delta 5.83$ (br s, $1 \mathrm{H}$ ), 4.08 (ddd, $J=12.3,6.5$, $6.5 \mathrm{~Hz}, 1 \mathrm{H}), 3.78-3.66(\mathrm{~m}, 4 \mathrm{H}), 3.60(\mathrm{ddd}, J=5.5,2.8,2.8 \mathrm{~Hz}, 1 \mathrm{H})$, $2.36(\mathrm{t}, J=7.6 \mathrm{~Hz}, 2 \mathrm{H}), 1.63(\mathrm{tt}, J=14.5,14.5 \mathrm{~Hz}, 3 \mathrm{H}), 1.31-1.19$ $(\mathrm{m}, 8 \mathrm{H}), 0.85(\mathrm{t}, J=6.7 \mathrm{~Hz}, 3 \mathrm{H}) .{ }^{13} \mathrm{C}\left\{{ }^{1} \mathrm{H}\right\} \mathrm{NMR}\left(100 \mathrm{MHz}, \mathrm{CDCl}_{3}\right)$ $\delta 172.5,89.0,67.7,66.0,61.7,34.3,31.6,29.0,28.8,24.7,22.5,14.0$. IR (film) $\nu_{\max } 2958,2930,2857,1747,1456,1232,1147,1069,917,856$, $756 \mathrm{~cm}^{-1}$; HRMS (ESI) calcd for $\mathrm{C}_{12} \mathrm{H}_{21} \mathrm{O}_{4}[\mathrm{M}-\mathrm{H}]^{-}$229.1440, found 229.1441 .

1,4-Dioxan-2-yl-thiophene-2-carboxylate (12). Yellow oil (391 $\mathrm{mg}, 73 \%) ;{ }^{1} \mathrm{H}$ NMR $\left(400 \mathrm{MHz}, \mathrm{CDCl}_{3}\right) \delta 7.88(\mathrm{dd}, J=3.8,1.3 \mathrm{~Hz}$, $1 \mathrm{H}), 7.59(\mathrm{dd}, J=5.0,1.3 \mathrm{~Hz}, 1 \mathrm{H}), 7.11(\mathrm{dd}, J=5.0,3.8 \mathrm{~Hz}, 1 \mathrm{H}), 6.04$ (br s, $1 \mathrm{H}), 4.20$ (ddd, $J=11.8,7.1,5.9 \mathrm{~Hz}, 1 \mathrm{H}), 3.86-3.85(\mathrm{~m}, 2 \mathrm{H})$, $3.81-3.79(\mathrm{~m}, 2 \mathrm{H}), 3.65(\mathrm{ddd}, J=5.3,2.6,2.6 \mathrm{~Hz}, 1 \mathrm{H}) ;{ }^{13} \mathrm{C}\left\{{ }^{1} \mathrm{H}\right\}$ NMR $\left(100 \mathrm{MHz}, \mathrm{CDCl}_{3}\right) \delta 160.8,134.1,133.2,127.8,89.9,67.7,66.0$, 61.8; IR (film) $\nu_{\max } 3103,2975,2858,1715,1418,1256,1062,1013$, 909, $750 \mathrm{~cm}^{-1}$; HRMS (ESI) calcd for $\mathrm{C}_{9} \mathrm{H}_{9} \mathrm{O}_{4} \mathrm{~S}[\mathrm{M}-\mathrm{H}]^{-}$213.0222, found 213.0226 .

1,4-Dioxan-2-yl 1-Naphthoate (13). White amorphous solid (336 mg, 52\%); ${ }^{1} \mathrm{H}$ NMR (400 MHz, $\left.\mathrm{CDCl}_{3}\right) \delta 9.02(\mathrm{~d}, J=8.7 \mathrm{~Hz}$, $1 \mathrm{H}), 8.35(\mathrm{dd}, J=7.3,1.3 \mathrm{~Hz}, 1 \mathrm{H}), 8.04(\mathrm{~d}, J=8.2 \mathrm{~Hz}, 1 \mathrm{H}), 7.88(\mathrm{~d}, J$ $=8.2 \mathrm{~Hz}, 1 \mathrm{H}), 7.63(\mathrm{ddd}, J=8.4,8.4,1.4 \mathrm{~Hz}, 1 \mathrm{H}), 7.54(\mathrm{ddd}, J=8.1$, 6.9, $1.2 \mathrm{~Hz}, 1 \mathrm{H}), 7.51(\mathrm{dd}, J=8.2,7.4 \mathrm{~Hz}, 1 \mathrm{H}), 6.21(\mathrm{br} \mathrm{s}, 1 \mathrm{H}), 4.26$ (ddd, $J=11.8,6.2,6.2 \mathrm{~Hz}, 1 \mathrm{H}), 3.96-3.95(\mathrm{~m}, 2 \mathrm{H}), 3.86-3.83(\mathrm{~m}$, $2 \mathrm{H}), 3.71$ (ddd, $J=5.2,2.6,2.6 \mathrm{~Hz}, 1 \mathrm{H}) ;{ }^{13} \mathrm{C}\left\{{ }^{1} \mathrm{H}\right\} \mathrm{NMR}(100 \mathrm{MHz}$, $\left.\mathrm{CDCl}_{3}\right) \delta 165.8,134.0,133.8,131.5,130.9,128.5,128.0,126.2,126.1$, 125.7, 124.4, 89.8, 67.9, 66.1, 61.8; IR (film) $\nu_{\text {max }} 2973,2856,1721$, 1510, 1233,1131, 1067, 883, $783 \mathrm{~cm}^{-1}$; HRMS (ESI) calcd for $\mathrm{C}_{15} \mathrm{H}_{13} \mathrm{O}_{4}[\mathrm{M}-\mathrm{H}]^{-}$257.0814, found 257.0815.

2-Styryl-1,4-dioxane (14). Yellowish amorphous solid (128 mg, $27 \%) ;{ }^{1} \mathrm{H}$ NMR (500 MHz, $\left.\mathrm{CDCl}_{3}\right) \delta 7.38(\mathrm{~d}, J=7.1 \mathrm{~Hz}, 2 \mathrm{H}), 7.31$ $(\mathrm{t}, J=7.5 \mathrm{~Hz}, 2 \mathrm{H}), 7.25(\mathrm{tt}, J=6.5,1.3 \mathrm{~Hz}, 1 \mathrm{H}), 6.69(\mathrm{~d}, J=16.1 \mathrm{~Hz}$, $1 \mathrm{H}), 6.09$ (dd, $J=16.1,6.2 \mathrm{~Hz}, 1 \mathrm{H}), 4.25$ (dddd, $J=10.1,6.2,2.8,1.4$ $\mathrm{Hz}, 1 \mathrm{H}), 3.89-3.80(\mathrm{~m}, 3 \mathrm{H}), 3.75$ (br dd, $J=11.6,2.6 \mathrm{~Hz}, 1 \mathrm{H}), 3.66$ (ddd, $J=11.5,10.8,3.2 \mathrm{~Hz}, 1 \mathrm{H}), 3.42(\mathrm{dd}, J=11.5,10.0 \mathrm{~Hz}, 1 \mathrm{H})$; ${ }^{13} \mathrm{C}\left\{{ }^{1} \mathrm{H}\right\}$ NMR $\left(126 \mathrm{MHz}, \mathrm{CDCl}_{3}\right) \delta 136.3,132.6,128.5,127.8,126.5$, 125.1, 76.0, 70.9, 66.6, 66.3; IR (film) $\nu_{\max } 3026,2968,2868,1452$, $1118,967,923,870,746,695 \mathrm{~cm}^{-1}$; HRMS (ESI) calcd for $\mathrm{C}_{12} \mathrm{H}_{15} \mathrm{O}_{2}$ $[\mathrm{M}+\mathrm{H}]^{+}$191.1072, found 191.1079.

1,4-Dithian-2-yl Benzoate (15). Yellowish amorphous solid (192 mg, 80\%); ${ }^{1} \mathrm{H}$ NMR (400 MHz, $\left.\mathrm{CDCl}_{3}\right) \delta 8.14(\mathrm{dd}, J=8.4,1.4 \mathrm{~Hz}$, $2 \mathrm{H}), 7.58(\mathrm{tt}, J=6.8,1.3 \mathrm{~Hz}, 1 \mathrm{H}), 7.46(\mathrm{dd}, J=7.8,7.8 \mathrm{~Hz}, 2 \mathrm{H}), 6.06$ $(\mathrm{dd}, J=5.0,1.9 \mathrm{~Hz}, 1 \mathrm{H}), 3.44-3.37(\mathrm{~m}, 2 \mathrm{H}), 3.10(\mathrm{dd}, J=11.7,11.7$ $\mathrm{Hz}, 1 \mathrm{H}), 3.01(\mathrm{dd}, J=14.2,5.1 \mathrm{~Hz}, 1 \mathrm{H}), 2.81-2.70(\mathrm{~m}, 2 \mathrm{H}) ;{ }^{13} \mathrm{C}\left\{{ }^{1} \mathrm{H}\right\}$ NMR (100 MHz, $\left.\mathrm{CDCl}_{3}\right) \delta 164.9,133.3,129.8,129.7,128.4,67.7$, 33.5, 28.0, 26.2; IR (film) $\nu_{\max } 3063,2911,1721,1601,1451,1324$, $1265,1095,1069,965,917,710 \mathrm{~cm}^{-1}$; HRMS (ESI) calcd for $\mathrm{C}_{11} \mathrm{H}_{12} \mathrm{O}_{2} \mathrm{~S}_{2} \mathrm{Na}[\mathrm{M}+\mathrm{Na}]^{+}$263.0176, found 263.0145.

1,4-Dithian-2-yl 4-Methylbenzoate (16). White amorphous solid (226 mg, 89\%); ${ }^{1} \mathrm{H}$ NMR (500 MHz, $\left.\mathrm{CDCl}_{3}\right) \delta 8.03$ (d, $J=$ $8.2 \mathrm{~Hz}, 2 \mathrm{H}), 7.26(\mathrm{~d}, J=7.9 \mathrm{~Hz}, 2 \mathrm{H}), 6.06($ br s, $1 \mathrm{H}), 3.41(\mathrm{br} \mathrm{s}, 2 \mathrm{H})$, 3.04 (br s, $2 \mathrm{H}), 2.77$ (br s, $2 \mathrm{H}), 2.41(\mathrm{~s}, 3 \mathrm{H}) ;{ }^{13} \mathrm{C}\left\{{ }^{1} \mathrm{H}\right\}$ NMR $(126$ $\left.\mathrm{MHz}, \mathrm{CDCl}_{3}\right): \delta 165.0,144.1,129.9,129.2,127.1,68.1,38.7,28.1$, 23.0, 21.7; IR (film) $\nu_{\max } 2913,1718,1612,1265,1092,914,749$ $\mathrm{cm}^{-1}$; HRMS (ESI) calcd for $\mathrm{C}_{12} \mathrm{H}_{14} \mathrm{O}_{2} \mathrm{~S}_{2} \mathrm{Na}[\mathrm{M}+\mathrm{Na}]^{+}$277.0333, found 277.0340 .

1,4-Dithian-2-yl 4-Methoxybenzoate (17). White amorphous solid (224 mg, 83\%); ${ }^{1} \mathrm{H}$ NMR (500 MHz, $\left.\mathrm{CDCl}_{3}\right) \delta 8.09$ (d, $J=9.0$ $\mathrm{Hz}, 2 \mathrm{H}), 6.93(\mathrm{~d}, J=8.9 \mathrm{~Hz}, 2 \mathrm{H}), 6.04(\mathrm{br} \mathrm{d}, J=3.7 \mathrm{~Hz}, 1 \mathrm{H}), 3.85(\mathrm{~s}$, $3 \mathrm{H}), 3.42-3.37(\mathrm{~m}, 2 \mathrm{H}), 3.10-2.98(\mathrm{~m}, 2 \mathrm{H}), 2.79-2.72(\mathrm{~m}, 2 \mathrm{H})$; ${ }^{13} \mathrm{C}\left\{{ }^{1} \mathrm{H}\right\}$ NMR $\left(126 \mathrm{MHz}, \mathrm{CDCl}_{3}\right) \delta 164.6,163.7,131.9,122.1,113.7$, 67.6, 55.4, 33.6, 28.1, 26.3; IR (film) $\nu_{\max } 2913,2839,1715,1606$, 1511, 1258, 1093, 1029, 967, 847, $769 \mathrm{~cm}^{-1}$; HRMS (ESI) calcd for $\mathrm{C}_{12} \mathrm{H}_{14} \mathrm{O}_{3} \mathrm{~S}_{2} \mathrm{Na}[\mathrm{M}+\mathrm{Na}]^{+}$293.0282, found 293.0288.

1,4-Dithian-2-yl 4-Chlorobenzoate (18). Yellowish amorphous solid (234 mg, 85\%); ${ }^{1} \mathrm{H}$ NMR $\left(500 \mathrm{MHz}, \mathrm{CDCl}_{3}\right) \delta 8.07$ (d, $J=8.8$ $\mathrm{Hz}, 2 \mathrm{H}), 7.43$ (d, $J=8.8 \mathrm{~Hz}, 2 \mathrm{H}), 6.05(\mathrm{br} \mathrm{d}, J=4.9 \mathrm{~Hz}, 1 \mathrm{H}), 3.44-$ $3.37(\mathrm{~m}, 2 \mathrm{H}), 3.10(\mathrm{dd}, J=12.5,12.5 \mathrm{~Hz}, 1 \mathrm{H}), 3.00(\mathrm{dd}, J=14.2,5.0$
$\mathrm{Hz}, 1 \mathrm{H}), 2.81-2.71(\mathrm{~m}, 2 \mathrm{H}) ;{ }^{13} \mathrm{C}\left\{{ }^{1} \mathrm{H}\right\}$ NMR $\left(126 \mathrm{MHz}, \mathrm{CDCl}_{3}\right) \delta$ 164.1, 139.8, 131.2, 128.8, 128.2, 68.1, 33.5, 28.1, 26.2; IR (film) $\nu_{\max }$ 2956, 2913, 1723, 1594, 1264, 1092, 1014, 964, 915, $757 \mathrm{~cm}^{-1}$; HRMS (ESI) calcd for $\mathrm{C}_{11} \mathrm{H}_{11} \mathrm{O}_{2} \mathrm{~S}_{2}{ }^{35} \mathrm{ClNa}[\mathrm{M}+\mathrm{Na}]^{+}$296.9787, found 296.9790; calcd for $\mathrm{C}_{11} \mathrm{H}_{11} \mathrm{O}_{2} \mathrm{~S}_{2}{ }^{37} \mathrm{ClNa}[\mathrm{M}+\mathrm{Na}]^{+} 298.9757$, found 298.9755.

1,4-Dithian-2-yl 4-Bromobenzoate (19). White amorphous solid $(287 \mathrm{mg}, 90 \%) ;{ }^{1} \mathrm{H}$ NMR $\left(500 \mathrm{MHz}, \mathrm{CDCl}_{3}\right) \delta 8.00(\mathrm{~d}, J=$ $8.7 \mathrm{~Hz}, 2 \mathrm{H}), 7.60(\mathrm{~d}, J=8.7 \mathrm{~Hz}, 2 \mathrm{H}), 6.05(\mathrm{br} \mathrm{d}, J=3.6 \mathrm{~Hz}, 1 \mathrm{H})$, $3.42-3.37(\mathrm{~m}, 2 \mathrm{H}), 3.15-2.93(\mathrm{~m}, 2 \mathrm{H}), 2.87-2.73(\mathrm{~m}, 2 \mathrm{H}) ;{ }^{13} \mathrm{C}\left\{{ }^{1} \mathrm{H}\right\}$ NMR $\left(126 \mathrm{MHz} \mathrm{CDCl}_{3}\right) \delta 164.3,131.8,131.4,128.7,128.6,68.2$, 33.4, 28.0, 26.3; IR (film) $\nu_{\max }$ 2912, 1725, 1590, 1398, 1263, 1096, 1011, 963, $753 \mathrm{~cm}^{-1}$; HRMS (ESI) calcd for $\mathrm{C}_{7} \mathrm{H}_{4} \mathrm{O}_{2}{ }^{79} \mathrm{Br}[\mathrm{M}-$ $\left.\mathrm{C}_{4} \mathrm{H}_{7} \mathrm{~S}_{2}\right]^{-}$198.9395, found 198.9391; calcd for $\mathrm{C}_{7} \mathrm{H}_{4} \mathrm{O}_{2}{ }^{81} \mathrm{Br}[\mathrm{M}-$ $\left.\mathrm{C}_{4} \mathrm{H}_{7} \mathrm{~S}_{2}\right]^{-}$200.9374, found 200.9372.

1,4-Dithian-2-yl Octanoate (20). Yellow oil (60 mg, 23\%); ${ }^{1} \mathrm{H}$ $\operatorname{NMR}\left(500 \mathrm{MHz}, \mathrm{CDCl}_{3}\right) \delta 5.82(\mathrm{dd}, J=5.2,1.9 \mathrm{~Hz}, 1 \mathrm{H}), 3.33-3.27$ (m, 2H), 3.10-2.97 (m, 1H), 2.88 (dd, $J=14.1,5.2 \mathrm{~Hz}, 1 \mathrm{H}), 2.76-$ $2.69(\mathrm{~m}, 2 \mathrm{H}), 2.39(\mathrm{t}, J=7.6 \mathrm{~Hz}, 2 \mathrm{H}), 1.65(\mathrm{tt}, J=14.7,14.7 \mathrm{~Hz}, 2 \mathrm{H})$, $1.31-1.25(\mathrm{~m}, 8 \mathrm{H}), 0.87(\mathrm{t}, J=5.2 \mathrm{~Hz}, 3 \mathrm{H}) ;{ }^{13} \mathrm{C}\left\{{ }^{1} \mathrm{H}\right\}$ NMR $(126$ $\left.\mathrm{MHz}, \mathrm{CDCl}_{3}\right) \delta 172.4,67.4,34.4,33.3,31.6,29.0,28.9,28.0,26.3$, 24.9, 22.6, 14.0; IR (film) $\nu_{\max } 2955,2927,2857,1740,1466,1153$, 966, $725 \mathrm{~cm}^{-1}$; HRMS (ESI) calcd for $\mathrm{C}_{12} \mathrm{H}_{22} \mathrm{O}_{2} \mathrm{~S}_{2} \mathrm{Na}[\mathrm{M}+\mathrm{Na}]^{+}$ 285.0959, found 285.0954

1,4-Dithian-2-yl Thiophene-2-carboxylate (21). Yellowish amorphous solid (101 mg, 41\%); ${ }^{1} \mathrm{H}$ NMR $\left(500 \mathrm{MHz}, \mathrm{CDCl}_{3}\right) \delta$ $7.90(\mathrm{dd}, J=3.8,1.3 \mathrm{~Hz}, 1 \mathrm{H}), 7.60(\mathrm{dd}, J=5.0,1.3 \mathrm{~Hz}, 1 \mathrm{H}), 7.12(\mathrm{dd}$, $J=5.0,3.8 \mathrm{~Hz}, 1 \mathrm{H}), 6.03-6.01(\mathrm{~m}, 1 \mathrm{H}), 3.42-3.37(\mathrm{~m}, 2 \mathrm{H}), 3.08$ (dd, $J=11.8,11.8 \mathrm{~Hz}, 1 \mathrm{H}), 3.00(\mathrm{dd}, J=14.2,5.2 \mathrm{~Hz}, 1 \mathrm{H}), 2.80-2.71$ (m, $2 \mathrm{H}) .{ }^{13} \mathrm{C}\left\{{ }^{1} \mathrm{H}\right\}$ NMR $\left(126 \mathrm{MHz}, \mathrm{CDCl}_{3}\right) \delta 160.6,134.1,133.2$, 133.1, 127.8, 68.2, 33.4, 28.0, 26.3; IR (film) $\nu_{\max } 3099,2911,1709$, $1523,1416,1253,1072,961,744 \mathrm{~cm}^{-1}$; HRMS (ESI) calcd for $\mathrm{C}_{9} \mathrm{H}_{10} \mathrm{O}_{2} \mathrm{~S}_{3} \mathrm{Na}[\mathrm{M}+\mathrm{Na}]^{+}$268.9741, found 268.9734.

1,4-Dithian-2-yl 1-Naphthoate (22). Yellowish amorphous solid (154 mg, 53\%); ${ }^{1} \mathrm{H}$ NMR (500 MHz, $\left.\mathrm{CDCl}_{3}\right) \delta 9.05(\mathrm{~d}, J=8.7 \mathrm{~Hz}$, $1 \mathrm{H}), 8.40(\mathrm{dd}, J=7.3,1.3 \mathrm{~Hz}, 1 \mathrm{H}), 8.05(\mathrm{~d}, J=8.2 \mathrm{~Hz}, 1 \mathrm{H}), 7.90-$ $7.88(\mathrm{~m}, 1 \mathrm{H}), 7.64(\mathrm{ddd}, J=8.6,5.6,1.4 \mathrm{~Hz}, 1 \mathrm{H}), 7.56-7.52(\mathrm{~m}, 2 \mathrm{H})$, 6.20-6.19 (m, 1H), 3.50-3.43 (m, 2H), 3.16-3.09 (m, 2H), 2.83$2.75(\mathrm{~m}, 2 \mathrm{H}) ;{ }^{13} \mathrm{C}\left\{{ }^{1} \mathrm{H}\right\}$ NMR $\left(126 \mathrm{MHz}, \mathrm{CDCl}_{3}\right) \delta 165.7,133.9$, 133.8, 131.4, 131.1, 128.6, 128.0, 126.3, 126.3, 125.8, 124.5, 68.1, 33.6, 28.1, 26.3; IR (film) $\nu_{\max } 3051,2911,1716,1510,1237,1191,1126$, 995, $780 \mathrm{~cm}^{-1}$; HRMS (ESI) calcd for $\mathrm{C}_{15} \mathrm{H}_{14} \mathrm{O}_{2} \mathrm{~S}_{2} \mathrm{Na}[\mathrm{M}+\mathrm{Na}]^{+}$ 313.0333, found 313.0347.

1,4-Dithian-2-yl Cinnamate (23). Yellow amorphous solid (69 $\mathrm{mg}, 26 \%) ;{ }^{1} \mathrm{H}$ NMR $\left(500 \mathrm{MHz}, \mathrm{CDCl}_{3}\right) \delta 7.78(\mathrm{~d}, J=16.0 \mathrm{~Hz}, 1 \mathrm{H})$, $7.56-7.54(\mathrm{~m}, 2 \mathrm{H}), 7.40-7.38(\mathrm{~m}, 3 \mathrm{H}), 6.53(\mathrm{~d}, J=16.0 \mathrm{~Hz}, 1 \mathrm{H})$, $5.97(\mathrm{dd}, J=5.2,2.0 \mathrm{~Hz}, 1 \mathrm{H}), 3.40-3.35(\mathrm{~m}, 2 \mathrm{H}), 3.07(\mathrm{dd}, J=11.5$, $11.5 \mathrm{~Hz}, 1 \mathrm{H}), 2.98(\mathrm{dd}, J=14.2,5.2 \mathrm{~Hz}, 1 \mathrm{H}), 2.80-2.72(\mathrm{~m}, 2 \mathrm{H})$; ${ }^{13} \mathrm{C}\left\{{ }^{1} \mathrm{H}\right\}$ NMR $\left(126 \mathrm{MHz}, \mathrm{CDCl}_{3}\right) \delta 165.4,146.0,134.2,130.5,128.9$, 128.2, 117.4, 67.7, 33.4, 28.0, 26.3; IR (film) $\nu_{\max } 3060,2911,1713$, 1636, 1336, 1151, 977, $768 \mathrm{~cm}^{-1}$; HRMS (ESI) calcd for $\mathrm{C}_{13} \mathrm{H}_{14} \mathrm{O}_{2} \mathrm{~S}_{2} \mathrm{Na}[\mathrm{M}+\mathrm{Na}]^{+}$289.0333, found 289.0342.

1-Methoxybutyl Benzoate and Butoxymethyl Benzoate (35a and 35b) (Mixture of Regioisomers). Colorless oil (120 mg, 23\%); ${ }^{1} \mathrm{H}$ NMR $\left(500 \mathrm{MHz}, \mathrm{CDCl}_{3}\right) \delta 8.12-8.03(\mathrm{~m}, 4 \mathrm{H}), 7.59-7.54(\mathrm{~m}$, $2 \mathrm{H}), 7.48-7.42(\mathrm{~m}, 4 \mathrm{H}), 6.02(\mathrm{t}, J=5.4 \mathrm{~Hz}, 1 \mathrm{H}), 5.54(\mathrm{~s}, 2 \mathrm{H}), 3.72$ $(\mathrm{t}, J=6.6 \mathrm{~Hz}, 2 \mathrm{H}), 3.47(\mathrm{~s}, 3 \mathrm{H}), 1.83-1.79(\mathrm{~m}, 2 \mathrm{H}), 1.64-1.58(\mathrm{~m}$, $2 \mathrm{H}), 1.51-1.44(\mathrm{~m}, 2 \mathrm{H}), 1.42-1.35(\mathrm{~m}, 2 \mathrm{H}), 0.96(\mathrm{t}, J=7.4 \mathrm{~Hz}, 3 \mathrm{H})$, $0.91(\mathrm{t}, J=7.4 \mathrm{~Hz}, 3 \mathrm{H}) ;{ }^{13} \mathrm{C}\left\{{ }^{1} \mathrm{H}\right\} \mathrm{NMR}\left(126 \mathrm{MHz}, \mathrm{CDCl}_{3}\right) \delta 166.3$, $166.0,133.1,133.1,130.1,129.95,129.7,129.5,128.4,128.4,100.4$, 90.0, 70.4, 56.7, 36.5, 31.5, 19.1, 17.3, 13.8, 13.7; HRMS (ESI) calcd for $\mathrm{C}_{12} \mathrm{H}_{16} \mathrm{O}_{3} \mathrm{Na}[\mathrm{M}+\mathrm{Na}]^{+}$231.0997, found 231.0994 for 35a; calcd for $\mathrm{C}_{12} \mathrm{H}_{16} \mathrm{O}_{3} \mathrm{Na}[\mathrm{M}+\mathrm{Na}]^{+}$231.0997, found 231.0993 for 35b.

1,2-Dimethoxyethyl Benzoate (36). Colorless oil (158 mg, $30 \%) ;{ }^{1} \mathrm{H}$ NMR $\left(500 \mathrm{MHz}, \mathrm{CDCl}_{3}\right) \delta 8.07(\mathrm{dd} J=8.4,1.3 \mathrm{~Hz}, 2 \mathrm{H})$, $7.56(\mathrm{tt}, J=7.4,7.4 \mathrm{~Hz}, 1 \mathrm{H}), 7.43(\mathrm{dd}, J=8.0,7.6 \mathrm{~Hz}, 2 \mathrm{H}), 6.12(\mathrm{dd}, J$ $=5.2,4.6 \mathrm{~Hz}, 1 \mathrm{H}), 3.62(\mathrm{dd}, J=10.7,5.3 \mathrm{~Hz}, 1 \mathrm{H}), 3.59(\mathrm{dd}, J=10.7$, $4.6 \mathrm{~Hz}, 1 \mathrm{H}), 3.52(\mathrm{~s}, 3 \mathrm{H}), 3.41(\mathrm{~s}, 3 \mathrm{H}) ;{ }^{13} \mathrm{C}\left\{{ }^{1} \mathrm{H}\right\}$ NMR $(126 \mathrm{MHz}$, $\left.\mathrm{CDCl}_{3}\right) \delta 166.0,133.3,129.8,129.5,128.3,97.4,72.7,59.5,57.1$; IR 
(film) $\nu_{\max }$ 2940, 1724, 1452, 1273, 1093, 926, $713 \mathrm{~cm}^{-1}$; HRMS (ESI) calcd for $\mathrm{C}_{11} \mathrm{H}_{14} \mathrm{O}_{4} \mathrm{Na}[\mathrm{M}+\mathrm{Na}]^{+}$233.0790, found 233.0783.

1,3-Dioxolan-4-yl Benzoate (38). Colorless oil (73 mg, 15\%); ${ }^{1} \mathrm{H}$ NMR $\left(500 \mathrm{MHz}, \mathrm{CDCl}_{3}\right) \delta 8.04(\mathrm{~d}, J=8.4 \mathrm{~Hz}, 2 \mathrm{H}), 7.59-7.56$ $(\mathrm{m}, 1 \mathrm{H}), 7.43(\mathrm{dd}, J=8.0,8.0 \mathrm{~Hz}, 2 \mathrm{H}), 6.58(\mathrm{dd}, J=4.1,1.9 \mathrm{~Hz}, 1 \mathrm{H})$, 5.19 (br s, $1 \mathrm{H}), 5.15$ (br s, $1 \mathrm{H}), 4.17(\mathrm{dd}, J=9.5,4.2 \mathrm{~Hz}, 1 \mathrm{H}), 4.12$ (dd, $J=9.5,1.9 \mathrm{~Hz}, 1 \mathrm{H}) ;{ }^{13} \mathrm{C}\left\{{ }^{1} \mathrm{H}\right\} \mathrm{NMR}\left(126 \mathrm{MHz}, \mathrm{CDCl}_{3}\right) \delta 165.8$, 133.5, 129.8, 129.4, 128.4, 95.9, 94.6, 70.7; IR (film) $\nu_{\max } 2881,1728$, $1452,1271,1092,922,712 \mathrm{~cm}^{-1}$; HRMS (ESI) calcd for $\mathrm{C}_{10} \mathrm{H}_{10} \mathrm{O}_{4} \mathrm{Na}$ $[\mathrm{M}+\mathrm{Na}]^{+} 217.0477$, found 217.0470 .

2-Methyl-1,3-dioxolan-2-yl Benzoate (39a). Colorless oil (270 $\mathrm{mg}, 52 \%) ;{ }^{1} \mathrm{H}$ NMR (400 MHz, $\left.\mathrm{CDCl}_{3}\right) \delta 8.00(\mathrm{dd}, J=8.4,1.4 \mathrm{~Hz}$, $2 \mathrm{H}), 7.52(\mathrm{tt}, J=6.8,1.3 \mathrm{~Hz}, 1 \mathrm{H}), 7.39(\mathrm{dd}, J=7.8,7.8 \mathrm{~Hz}, 2 \mathrm{H})$, 4.48-4.46 (m, 2H), 4.38-4.35 (m, 2H), $2.04(\mathrm{~s}, 3 \mathrm{H}) ;{ }^{13} \mathrm{C}\left\{{ }^{1} \mathrm{H}\right\} \mathrm{NMR}$ $\left(120 \mathrm{MHz}, \mathrm{CDCl}_{3}\right) \delta 170.6,166.1,133.0,129.6,129.5,128.2,62.5$, 62.0, 20.6; IR (film) $\nu_{\max } 2960,1743,1722,1452,1375,1278,1232$, 1062, $712 \mathrm{~cm}^{-1}$; HRMS (ESI) calcd for $\mathrm{C}_{11} \mathrm{H}_{12} \mathrm{O}_{4} \mathrm{Na}[\mathrm{M}+\mathrm{Na}]^{+}$ 231.0633, found 231.0628 .

trans-2-Methyl-1,3-dioxolan-4-yl Benzoate (39b). Colorless oil (52 mg, 10\%); ${ }^{1} \mathrm{H}$ NMR (400 MHz, $\left.\mathrm{CDCl}_{3}\right) \delta 8.04$ (dd, $J=8.4,1.3$ $\mathrm{Hz}, 2 \mathrm{H}), 7.58(\mathrm{tt}, J=6.9,1.3 \mathrm{~Hz}, 1 \mathrm{H}), 7.44(\mathrm{dd}, J=8.0,8.0 \mathrm{~Hz}, 2 \mathrm{H})$, $6.57(\mathrm{dd}, J=4.8,2.7 \mathrm{~Hz}, 1 \mathrm{H}), 5.37(\mathrm{q}, J=4.8 \mathrm{~Hz}, 1 \mathrm{H}), 4.37(\mathrm{dd}, J=$ 9.5, $4.8 \mathrm{~Hz}, 1 \mathrm{H}), 4.01(\mathrm{dd}, J=9.5,2.7 \mathrm{~Hz}, 1 \mathrm{H}), 1.45(\mathrm{~d}, J=4.9 \mathrm{~Hz}$, $3 \mathrm{H}) ;{ }^{13} \mathrm{C}\left\{{ }^{1} \mathrm{H}\right\}$ NMR $\left(100 \mathrm{MHz}, \mathrm{CDCl}_{3}\right) \delta 165.8,133.5,129.8,129.5$, 128.4, 102.4, 95.5, 71.0, 19.2; IR (film) $\nu_{\max } 2994,2894,1729,1452$, $1272,1158,1057,981,712 \mathrm{~cm}^{-1}$; HRMS (ESI) calcd for $\mathrm{C}_{11} \mathrm{H}_{12} \mathrm{O}_{4} \mathrm{Na}$ $[\mathrm{M}+\mathrm{Na}]^{+} 231.0633$, found 231.0626 .

cis-2-Methyl-1,3-dioxolan-4-yl Benzoate (39c). Colorless oil $(21 \mathrm{mg}, 4 \%) ;{ }^{1} \mathrm{H}$ NMR $\left(400 \mathrm{MHz}, \mathrm{CDCl}_{3}\right) \delta 8.05(\mathrm{dd}, J=8.4,1.3 \mathrm{~Hz}$, $2 \mathrm{H}), 7.58(\mathrm{tt}, J=6.9,1.3 \mathrm{~Hz}, 1 \mathrm{H}), 7.45(\mathrm{dd}, J=7.9,7.9 \mathrm{~Hz}, 2 \mathrm{H}), 6.52$ $(\mathrm{d}, J=3.6 \mathrm{~Hz}, 1 \mathrm{H}), 5.31(\mathrm{q}, J=4.9 \mathrm{~Hz}, 1 \mathrm{H}), 4.32(\mathrm{~d}, J=9.8 \mathrm{~Hz}, 1 \mathrm{H})$, $4.02(\mathrm{dd}, J=9.8,3.7 \mathrm{~Hz}, 1 \mathrm{H}), 1.51(\mathrm{~d}, J=4.9 \mathrm{~Hz}, 3 \mathrm{H}) ;{ }^{13} \mathrm{C}\left\{{ }^{1} \mathrm{H}\right\} \mathrm{NMR}$ $\left(100 \mathrm{MHz}, \mathrm{CDCl}_{3}\right) \delta 165.9,133.4,129.8,129.7,128.4,104.6,94.9$, 71.6, 21.2; IR (film) $\nu_{\max }$ 2999, 2884, 1726, 1272, 1157, 1067, 1024, 981, $712 \mathrm{~cm}^{-1}$; HRMS (ESI) calcd for $\mathrm{C}_{11} \mathrm{H}_{12} \mathrm{O}_{4} \mathrm{Na}[\mathrm{M}+\mathrm{Na}]^{+}$ 231.0633, found 231.0634.

Tetrahydrothiophen-2-yl Benzoate (40). Yellowish amorphous solid (96 mg, 46\%); ${ }^{1} \mathrm{H}$ NMR (500 MHz, $\left.\mathrm{CDCl}_{3}\right) \delta 8.01$ (dd, $J=8.3$, $1.2 \mathrm{~Hz}, 2 \mathrm{H}), 7.56-7.52(\mathrm{~m}, 1 \mathrm{H}), 7.43-7.40(\mathrm{~m}, 2 \mathrm{H}), 6.42(\mathrm{dd}, J=$ $4.8,1.4 \mathrm{~Hz}, 1 \mathrm{H}), 3.07$ (ddd, $J=9.8,7.1,2.3 \mathrm{~Hz}, 1 \mathrm{H}), 2.86$ (ddd, $J=$ $10.4,10.4,6.2 \mathrm{~Hz}, 1 \mathrm{H}), 2.46-2.42(\mathrm{~m}, 1 \mathrm{H}), 2.31-2.24(\mathrm{~m}, 1 \mathrm{H})$, $2.21-2.11(\mathrm{~m}, 1 \mathrm{H}), 2.06-1.98(\mathrm{~m}, 1 \mathrm{H}) ;{ }^{13} \mathrm{C}\left\{{ }^{1} \mathrm{H}\right\}$ NMR (126 MHz, $\left.\mathrm{CDCl}_{3}\right) \delta 166.0,133.0,130.1,129.6,128.3,83.6,37.4,32.4,28.4$; IR (film) $\nu_{\max } 2961,2936,1717,1451,1269,1096,1025,921,710 \mathrm{~cm}^{-1}$; HRMS (ESI) calcd for $\mathrm{C}_{11} \mathrm{H}_{12} \mathrm{O}_{2} \mathrm{SNa}[\mathrm{M}+\mathrm{Na}]^{+}$231.0456, found 231.0453.

1,4-Oxathian-3-yl Benzoate (41a). White amorphous solid (308 $\mathrm{mg}, 55 \%) ;{ }^{1} \mathrm{H}$ NMR (500 MHz, $\left.\mathrm{CDCl}_{3}\right) \delta 8.12(\mathrm{dd}, J=8.4,1.3 \mathrm{~Hz}$, $2 \mathrm{H}), 7.57(\mathrm{tt}, J=7.4,1.3 \mathrm{~Hz}, 1 \mathrm{H}), 7.45(\mathrm{dd}, J=7.8,7.8 \mathrm{~Hz}, 2 \mathrm{H}), 5.79$ (br s, $1 \mathrm{H}), 4.27$ (br s, $1 \mathrm{H}), 4.24$ (br s, $1 \mathrm{H}), 4.02(\mathrm{dd}, J=12.6,1.7 \mathrm{~Hz}$, $1 \mathrm{H}), 3.86$ (ddd, $J=11.8,11.8,2.0 \mathrm{~Hz}, 1 \mathrm{H}), 3.39-3.34(\mathrm{~m}, 1 \mathrm{H}), 2.30$ (br d, $J=13.6 \mathrm{~Hz}, 1 \mathrm{H}) ;{ }^{13} \mathrm{C}\left\{{ }^{1} \mathrm{H}\right\} \mathrm{NMR}\left(126 \mathrm{MHz}, \mathrm{CDCl}_{3}\right) \delta 165.35$, 133.3, 129.9, 129.8, 128.4, 71.2, 68.7, 68.0, 23.5; IR (film) $\nu_{\max } 3063$, 2952, 2854, 1719, 1451,1262, 1097, 1008, $711 \mathrm{~cm}^{-1}$; HRMS (ESI) calcd for $\mathrm{C}_{11} \mathrm{H}_{12} \mathrm{O}_{3} \mathrm{SNa}[\mathrm{M}+\mathrm{Na}]^{+} 247.0405$, found 247.0404 .

1,4-Oxathian-2-yl Benzoate (41b). White amorphous solid (84 $\mathrm{mg}, 15 \%) ;{ }^{1} \mathrm{H}$ NMR $\left(500 \mathrm{MHz}, \mathrm{CDCl}_{3}\right) \delta 8.10(\mathrm{dd}, J=8.4,1.3 \mathrm{~Hz}$, $2 \mathrm{H}), 7.58-7.56(\mathrm{~m}, 1 \mathrm{H}), 7.45(\mathrm{dd}, J=7.7 ., 7.7 \mathrm{~Hz}, 2 \mathrm{H}), 6.17$ (br s, $1 \mathrm{H}), 4.35$ (br s, $1 \mathrm{H}), 4.01$ (br s, $1 \mathrm{H}), 2.83$ (br s, $2 \mathrm{H}), 2.64$ (br s, $2 \mathrm{H}$ ); ${ }^{13} \mathrm{C}\left\{{ }^{1} \mathrm{H}\right\}$ NMR $\left(126 \mathrm{MHz}, \mathrm{CDCl}_{3}\right) \delta 164.7,133.4,129.86,129.5$, 128.4, 91.2, 66.0, 29.5, 25.8; IR (film) $\nu_{\max } 3063,2920,1728,1452$, 1269, 1062, $955 \mathrm{~cm}^{-1}$; HRMS (ESI) calcd for $\mathrm{C}_{11} \mathrm{H}_{12} \mathrm{O}_{3} \mathrm{SNa}[\mathrm{M}+$ $\mathrm{Na}]^{+}$247.0405, found 247.0402 .

\section{ASSOCIATED CONTENT}

\section{(S Supporting Information}

Physical characterization of the catalyst and NMR spectra for all compounds. The Supporting Information is available free of charge on the ACS Publications website at DOI: 10.1021/ acs.joc.5b01043.

\section{AUTHOR INFORMATION}

\section{Corresponding Author}

*E-mail: francisco.guerra@uca.es.

\section{Notes}

The authors declare no competing financial interest.

\section{ACKNOWLEDGMENTS}

We are grateful to the Ministry of Economy and Competitiveness of Spain (Projects AGL2013-42238-R, CSD2009-00013, and MINECO/FEDER MAT2013-40823-R) and the Junta de Andalucía (FQM-169 and FQM-110 groups) for financial support. A.L.G.-C. and R.M.-B. acknowledge the Spanish Ministry of Education, Culture and Sport for fellowships. We also thank the SC-ICYT of the University of Cádiz for the use of its XRD, AS, NMR, and electron microscopy division facilities.

\section{REFERENCES}

(1) (a) C-H Activation in Top. Curr. Chem.; Yu, J.-Q.; Shi, Z., Eds.; Springer-Verlag: Berlin, 2010, Vol. 292. (b) Handbook of $C-H$ Transformations: Applications in Organic Synthesis; Dyker, G., Ed.; Wiley-VCH: Weinheim, 2005. (c) Smith, A. M. R; Hii, K. K. Chem. Rev. 2011, 111, 1637-1656. (d) Sun, C. L.; Li, B. J.; Shi, Z. J. Chem. Rev. 2011, 111, 1293-1314. (e) Ackermann, L. Chem. Rev. 2011, 111, 1315-1345. (f) Wendlandt, A. E.; Suess, A. M.; Stahl, S. S. Angew. Chem., Int. Ed. 2011, 50, 11062-11087. (g) Wencel-Delord, J.; Dröge, T.; Liu, F.; Glorius, F. Chem. Soc. Rev. 2011, 40, 4740-4761.

(2) (a) White, M. C. Synlett 2012, 23, 2746-2748. (b) Lyons, T. W.; Sanford, M. S. Chem. Rev. 2010, 110, 1147-1169. (c) Giri, R.; Shi, B.F.; Engle, K. M.; Maugel, N.; Yu, J.-Q. Chem. Soc. Rev. 2009, 38, 32423272.

(3) (a) Krylov, I. B.; Vil', V. A.; Terent'ev, A. A. Beilstein J. Org. Chem. 2015, 11, 92-146. (b) Zhao, J.; Fang, H.; Zhou, W.; Han, J.; Pan, Y. Org. Chem. 2014, 79, 3847-3855. (c) Majji, G.; Guin, S.; Rout, S. K.; Behera, A.; Patel, B. K. Chem. Commun. 2014, 50, 12193-12196.

(4) Wang, Q.; Zheng, H.; Chai, W.; Chen, D.; Zeng, X.; Fu, R.; Yuan, R. Org. Biomol. Chem. 2014, 12, 6549-6553.

(5) Rout, S. K.; Guin, S.; Ali, W.; Gogoi, A.; Patel, B. K. Org. Lett. 2014, 16, 3086-3089.

(6) (a) Hronowski, L. J. J.; Szarek, W. A. J. Med. Chem. 1982, 25, 522-526. (b) Sosnovsky, G.; Yang, N. C. J. Org. Chem. 1960, 25, 899903.

(7) (a) Wang, Q.; Geng, H.; Chai, W.; Zeng, X.; Xu, M.; Zhu, C.; Fu, R.; Yuan, R. Eur. J. Org. Chem. 2014, 31, 6850-6853. (b) Priyadarshini, S.; Amal Joseph, P. J.; Lakshmi Kantam, M. RSC Adv. 2013, 3, 1828318287. (c) Liu, Z.-Q.; Zhao, L.; Shang, X.; Cui, Z. Org. Lett. 2012, 14, 3218-3221. (d) Kumar, G. S.; Pieber, B.; Reddy, K. R.; Kappe, C. O. Chem.-Eur. J. 2012, 18, 6124-6128.

(8) (a) Zhao, J.; Fang, H.; Zhou, W.; Han, J.; Pan, Y. J. Org. Chem. 2014, 79, 3847-3855. (b) Barve, B. D.; Wu, Y.-C.; El-Shazly, M.; Korinek, M.; Cheng, Y.-B.; Wang, J.-J.; Chang, F.-R. Org. Lett. 2014, 16, 1912-1915.

(9) (a) Majji, G.; Rajamanickam, S.; Khatun, N.; Santra, S. K.; Patel, B. K. J. Org. Chem. 2015, 80, 3440-3446. (b) Wang, Q.; Feng, J.; Chai, W.; Geng, H.; Xu, M.; Wang, K.; Xu, C.; Fu, R.; Yuan, R. Tetrahedron Lett. 2014, 55, 4785-4789. (c) Guo, S.; Yu, J.; Dai, Q.; Yang, H.; Cheng, J. Chem. Commun. 2014, 50, 6240-6242. (d) Zhu, F.; Wang, Z.-X. Tetrahedron 2014, 70, 9819. (e) Chen, L.; Shi, E.; Liu, Z.; Chen, S.; Wei, W.; Li, H.; Xu, K.; Wan, X. Chem.-Eur. J. 2011, 17, 40854089.

(10) Zheng, Y.; Mao, J.; Rong, G.; Xu, X. Chem. Commun. 2015, 51, $8837-8840$. 
(11) Cao, Q.; Dornan, L. M.; Rogan, L.; Hughes, N. L.; Muldoon, M. J. Chem. Commun. 2014, 50, 4524-4543.

(12) (a) Debecker, D. P.; Hulea, V.; Mutin, P. H. Appl. Catal., A 2013, 451, 192-206. (b) Carpentier, J.; Lamonier, J.-F.; Siffert, S.; Laversin, H.; Aboukaïs, A. In Stud. Surf. Sci. Catal.; Aiello, R., Giordano, G., Testa, F., Eds.; Elsevier Science B.V.: Taormina, 2002; Vol. 142, pp 1197-1204.

(13) (a) García-Cabeza, A. L.; Marín-Barrios, R.; Moreno-Dorado, F. J.; Ortega, M. J.; Massanet, G. M.; Guerra, F. M. Org. Lett. 2014, 16, 1598-1601. (b) García-Cabeza, A. L.; Marín-Barrios, R.; Azarken, R.; Moreno-Dorado, F. J.; Ortega, M. J.; Vidal, H.; Gatica, J. M.; Massanet, G. M.; Guerra, F. M. Eur. J. Org. Chem. 2013, 36, 8307-8314.

(14) Guida, A.; Lhouty, M. H.; Tichit, D.; Figueras, F.; Geneste, P. Appl. Catal., A 1997, 164, 251-264.

(15) Wei, W.; Zhang, C.; Xu, Y.; Wan, X. Chem. Commun. 2011, 47, 10827-10829.

(16) Wang, C.-Y.; Song, R.-J.; Wei, W.-T.; Fan, J.-H.; Li, J.-H. Chem. Commun. 2015, 51, 2361-2363.

(17) Zhao, J.; Zhou, W.; Han, J.; Li, G.; Pan, Y. Tetrahedron Lett. 2013, 54, 6507-6510.

(18) Müller, A.; Diemann, E. In Comprehensive Coordination Chemistry; Wilkinson, G., Ed.; Pergamon: Oxford, 1987; Vol. 2, pp 515-550.

(19) (a) Yang, D.; Zhu, X.; Wei, W.; Sun, N.; Yuan, L.; Jiang, M.; You, J.; Wang, H. RSC Adv. 2014, 4, 17832-17839. (b) Hudson, R. Synlett 2013, 24, 1309-1310. (c) Hudson, R.; Ishikawa, S.; Li, C.-J.; Moores, A. Synlett 2013, 24, 1637-1642. (d) Avudoddi, V.; Palle, V. K. G.; Pallapothula, V. R. Eur. J. Chem. 2012, 3, 298-304.

(20) Newhouse, T.; Baran, P. S. Angew. Chem., Int. Ed. 2011, 50, $3362-3374$.

(21) Müller, A.; Diemann, E. In Comprehensive Coordination Chemistry; Wilkinson, G., Ed.; Pergamon: Oxford, 1987; Vol. 2, pp 551-558.

(22) Berkessel, A.; Vogl, N. In The Chemistry of Peroxides; Rappoport, Z., Ed.; John Wiley and Sons: Chichester, 2006; Vol. 2, Part 1, pp 307-596.

(23) Liu, Y.-J.; Xu, H.; Kong, W.-J.; Shang, M.; Dai, H.-X.; Yu, J.-Q. Nature 2014, 515, 389-393.

(24) Rodríguez-Carvajal, J. J. Phys. B (Amsterdam, Neth.) 1993, 192, $55-69$. 